\title{
The Niederschlag fluorite-(barite) deposit, Erzgebirge/Germany-a fluid inclusion and trace element study
}

\author{
Sebastian Haschke ${ }^{1}$ (i) $\cdot$ Jens Gutzmer ${ }^{2} \cdot$ Cora C. Wohlgemuth-Ueberwasser ${ }^{3} \cdot$ Dennis Kraemer $^{4} \cdot$ Mathias Burisch $^{1}$
}

Received: 9 April 2020 / Accepted: 4 December 2020 / Published online: 5 January 2021

(C) The Author(s) 2021

\begin{abstract}
The Niederschlag fluorite-barite vein deposit in the Western Erzgebirge, Germany, has been actively mined since 2013. We present the results of a first comprehensive study of the mineralogy, petrography, fluid inclusions, and trace element geochemistry of fluorite related to the Niederschlag deposit. Two different stages of fluorite mineralization are recognized. Stage I fluorite is older, fine-grained, associated with quartz, and forms complex breccia and replacement textures. Conversely, the younger Stage II fluorite is accompanied by barite and often occurs as banded and coarse crystalline open-space infill. Fluid inclusion and REY systematics are distinctly different for these two fluorite stages. Fluid inclusions in fluorite I reveal the presence of a low to medium saline $\left(7-20 \%\right.$ eq. $\mathrm{w}\left(\mathrm{NaCl}+\mathrm{CaCl}_{2}\right)$ ) fluid with homogenization temperatures of $140-180{ }^{\circ} \mathrm{C}$, whereas fluorite II inclusions yield distinctly lower $\left(80-120^{\circ} \mathrm{C}\right)$ homogenization temperatures with at least two high salinity fluids involved (18$27 \%$ eq. $\left.\mathrm{w}\left(\mathrm{NaCl}+\mathrm{CaCl}_{2}\right)\right)$. In the absence of geochronological data, the genesis of the earlier generation of fluorite-quartz mineralization remains enigmatic but is tentatively related to Permian magmatism in the Erzgebirge. The younger fluoritebarite mineralization, on the other hand, has similarities to many fluorite-barite- $\mathrm{Pb}-\mathrm{Zn}-\mathrm{Cu}$ vein deposits in Europe that are widely accepted to be related to the Mesozoic opening of the northern Atlantic Ocean.
\end{abstract}

Keywords Fluorite $\cdot$ Microthermometry $\cdot$ Fluid inclusions $\cdot$ Rare earth elements $\cdot$ Geochemistry $\cdot$ Metallogenesis $\cdot$ Industrial minerals

\section{Introduction}

The Niederschlag fluorite-barite mine is located close to the town of Oberwiesenthal in the Western Erzgebirge of Germany. It commenced operation in 2013 and is owned and operated by the Erzgebirgische Fluß- und

Editorial handling: H. Frimmel

Sebastian Haschke

sebastian.haschke@mineral.tu-freiberg.de

Mathias Burisch

mathias.burisch@mineral.tu-freiberg.de

1 Institut für Mineralogie, Technische Universität Bergakademie Freiberg, Freiberg, Germany

2 Helmholtz-Zentrum Dresden-Rossendorf, Helmholtz Institut Freiberg für Ressourcentechnologie, Freiberg, Germany

3 German Research Centre for Geosciences, GFZ, Telegrafenberg, 14473 Potsdam, Germany

4 Department of Physics and Earth Sciences, Jacobs University Bremen, Campus Ring 1, 28759 Bremen, Germany
Schwerspatwerke GmbH (EFS). As the only active fluoritebarite mine in the Erzgebirge, the Niederschlag deposit produces around 100,000 $t$ of raw fluorite concentrate per year, corresponding to ca. 20,000 t of acid grade fluorite product. Initially, barite was also exploited from the shallower parts of the deposit and processed at the Clara mine, Schwarzwald (Kuhn and Duba 2017). The production of barite concentrates has, however, been discontinued.

The major ore body at the Niederschlag deposit is $\sim 3-12 \mathrm{~m}$ thick, steeply dipping vein with a strike length of about $1 \mathrm{~km}$, which extends from Germany across the border into the Czech Republic. On the Czech side, the vein is referred to as the Kovarska deposit; the name Niederschlag deposit thus only refers to the vein on the German side. Inferred resources for the Niederschlag deposit were last reported by (Kuschka 2002) as $\sim 1.15 \mathrm{Mt}$ of fluorite and $0.56 \mathrm{Mt}$ of barite. The shallowest portion of the Niederschlag vein system is also marked by the occurrence of five-element mineralization, which was historically exploited for silver and cobalt from medieval times until the nineteenth century (Lipp and Flach 2003). After World War II, intense exploration for uranium 
was carried out and around $132.7 \mathrm{t}$ of uranium were produced between 1949 and 1954 (Wismut 1999). The fluorite mineralization was only discovered during (rather unsuccessful) exploration of uranium resources of deeper portions of the Niederschlag vein. Uranium mining thus ceased in 1954, when all known reserves of uranium mineralization had been mined out.

The fluorite-barite mineralization of the Niederschlag deposit received renewed interest during the 1970s, when stateowned companies of the German Democratic Republic (GDR) carried out an extensive exploration program aimed to constrain fluorite and barite resources (Kuschka 2002). At the time, the decision was taken to retain the resources of the Niederschlag deposit for later development. It is thus not surprising that the decision of the EFS to develop the current mining operation was based essentially on GDR exploration results. In fact, no new drill cores were obtained and mineral processing test work was based on historic bulk samples that were still available at surface from the 1970's exploration program.

Besides the Niederschlag deposit, there are several fluoritebarite vein deposits known in the Erzgebirge region (Baumann et al. 2000). All these deposits, though mined in the past, are currently regarded sub-economic; however, these may well become interesting targets for renewed exploration, especially since fluorite and barite are considered as critical raw materials by the EU Commission (2017). Arguably the most important example is the Schönbrunn-Bösenbrunn deposit that was a major fluorite producer until 1991 when it was closed as a consequence of German reunification (Kuschka and Hahn 1996). The Freiberg district, on the other hand, was a major producer of fluorite and barite until 1969 (Wagenbreth 1988).

The known fluorite-barite veins have in common that the available geoscientific literature is rather generic (Kuschka 2002) and that modern geochemical data is scant. Genetic models are thus outdated or not available at all. A notable exceptions are recent studies on the Freiberg district (Bauer et al. 2019; Ostendorf et al. 2019), where Sm-Nd geochronology and fluid inclusion analyses have illustrated that fluoritebarite mineralization is of Mesozoic age and related to the migration and mixing of shallow crustal, highly saline brines. This mineralization style is very similar to many other fluorite-barite veins known from Variscan basement exposures in Europe, with examples from Germany, France, Spain, Poland, Czech Republic, and Great Britain (Boiron et al. 2010; Kraemer et al. 2019; Muchez et al. 2005; Walter et al. 2016). The formation of this vein-style mineralization is typically related to the opening of the northern Atlantic in the Cretaceous (Walter et al. 2018b) and that share fluid inclusion systematics (e.g., (Baatartsogt et al. 2007; Walter et al. 2017)).

This contribution is dedicated to place first constraints on the origin of fluorite-barite mineralization of the Niederschlag deposit. For this purpose, field geological and petrographic studies were complemented by bulk rock (solution ICP-MS) and in situ trace element (LA-ICP-MS) analyses of different generations of fluorite in order to reconstruct hydrothermal fluids and ore-forming processes. The results are compared with other examples of vein-type fluorite-barite deposits in the Erzgebirge (Trinkler et al. 2005; Wolff et al. 2015b) and elsewhere in Central Europe (Bau and Dulski 1995; Nadoll et al. 2019; Schwinn and Markl 2005).

\section{Regional geological setting}

Fluorite-barite mineralization of the Niederschlag deposit is hosted by Latest Neoproterozoic to Early Paleozoic (570$460 \mathrm{Ma}$ ) sedimentary and igneous units of the SaxoThuringian Zone as a part of the Variscan Orogenic belt (Rötzler and Plessen 2010). These were deformed and metamorphosed during the Paleozoic collision of Gondwana and Laurussia (Kroner and Romer 2013) with peak metamorphism timed at $340 \mathrm{Ma}$ (Kröner and Willner 1998). The metamorphic basement units were intruded by voluminous granitoids (330-315 Ma; (Tichomirowa and Leonhardt 2010), rhyolitic and lamprophyre dikes (Romer et al. 2010; von Seckendorff et al. 2004; Seifert 2008) (Fig. 1a). Felsic magmatism (325$285 \mathrm{Ma}$ ) during the late stages of orogenic collapse (Förster et al. 2007; Hoffmann et al. 2013) was closely associated with the formation of a variety of types of magmatic-hydrothermal ore deposits in the Erzgebirge (Burisch et al. 2019; Ostendorf et al. 2019; Zhang et al. 2017).

The Post-Variscan geological evolution of the Erzgebirge is poorly constrained due to the almost complete erosion of the former cover succession. It has, however, been inferred that subsidence and concomitant basin formation following the Variscan Orogeny led to a thick sedimentary cover, overlying the Variscan basement units (Pälchen and Walter 2008). Apatite fission-track thermochronology indicates that the maximum thickness of the sedimentary cover reached 2 $3 \mathrm{~km}$ during the Mesozoic (Wolff et al. 2015a). During the Cretaceous, the Elbe rift graben was reactivated, which led to marine transgressions and sedimentation.

Exhumation of the Erzgebirge was related to the Cenozoic Eger rift, which was accompanied by the emplacement of abundant phonolitic and basaltic dikes. Rifting also resulted in uplift and erosion of the Erzgebirge block, eventually resulting in the exposure of the metamorphic units - and the ore deposits hosted therein (Pälchen and Walter 2008).

\section{Local geological setting}

Numerous hydrothermal veins with different styles of mineralization are known from the Niederschlag-Bärenstein district, which spans across an area of $\sim 10 \times 15 \mathrm{~km}$. Veins comprise different stages and styles of mineralization, which include 


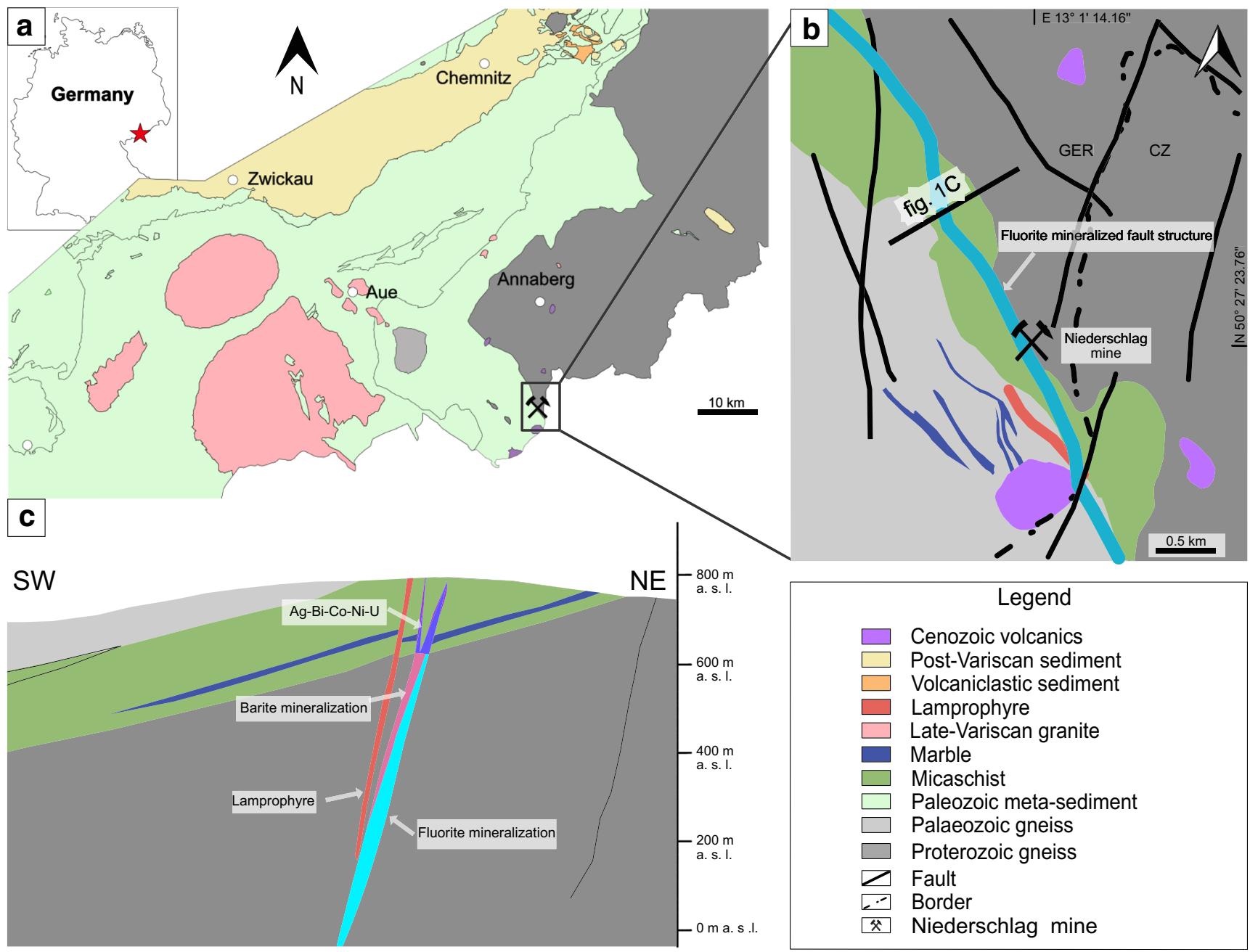

Fig. 1 a Simplified geological map of the Erzgebirge and the Niederschlag mining district (modified after Sächsisches Landesamt für Umwelt, 1994 and (Baumann et al. 2000)). Main lithologies are gneisses of the Cadomian basement (E-Erzgebirge) (Tichomirowa et al. 2012) and metamorphosed Paleozoic sediments (W-Erzgebirge) (Mingram 1998),

Sn-quartz, polymetallic-Pb-Zn- $(\mathrm{Cu})$-quartz, Ucarbonate-(quartz), fluorite-quartz, fluorite-barite- $\mathrm{Pb}-\mathrm{Zn}-\mathrm{Cu}-$ sulfides, and $\mathrm{Ag}$-Bi-Co-Ni-As-carbonate (five element association) assemblages. Most of these veins are sub-economic (Fig. 1c). The Niederschlag fluorite-barite vein deposit is related to the Scheibenberg-Niederschlag-Kovàrskà-fault, a discrete NNW-SSE striking fault system that is mineralized along a strike length of $\sim 2.5 \mathrm{~km}$. The economically relevant fluorite resource is, however, restricted to an only $\sim 1 \mathrm{~km}$-long segment of the structure, with vein thickness ranging from 4 to $12 \mathrm{~m}$ (Kuschka 2002). The upper levels of the Niederschlag deposit cut across a diverse set of rock types comprising garnet-muscovite schist, paragneisses, marble, quartzite as well as graphite-rich schist - all belonging to a high-pressure low-temperature metasedimentary nappe structure of the passive Gondwana margin having protolith ages of 460-500 Ma (Mingram 1998; Rötzler and Plessen 2010). Approximately besides late Variscan granites (Förster et al. 1999). Cenozoic volcanic lithologies are related to the Egergraben-rifting. b Enlarged geological map of the Niederschlag area modified after Baumann et al. 2000. c Simplified SW-NE cross-section (Leonhardt 1999) through the zoned Niederschlag fluorite-barite deposit.

$200 \mathrm{~m}$ below the present-day land surface, the host lithology changes from carbon-rich metasedimentary units to para- and orthogneisses.

\section{Hydrothermal mineralization and vertical zoning}

Mineralization at Niederschlag is polystadial and shows vertical zoning that has been described in great detail by Kuschka (2002). The most shallow part of the vein predominantly comprises of a five element vein assemblage (U-Ag-Co-Ni-As minerals) associated with fluorite, barite, carbonates, and quartz ("U-Bi-Co-Ni" after Kuschka 2002). With increasing depth, the abundance of fluorite increases at the expense of barite and U-Ag-Co-Ni-As minerals. Seventy meters below the modern ground level (m.b.g.l.), fluorite and barite prevail (Fig. 1c). It is the latter assemblage that is currently being exploited and that has been the subject of this investigation. 


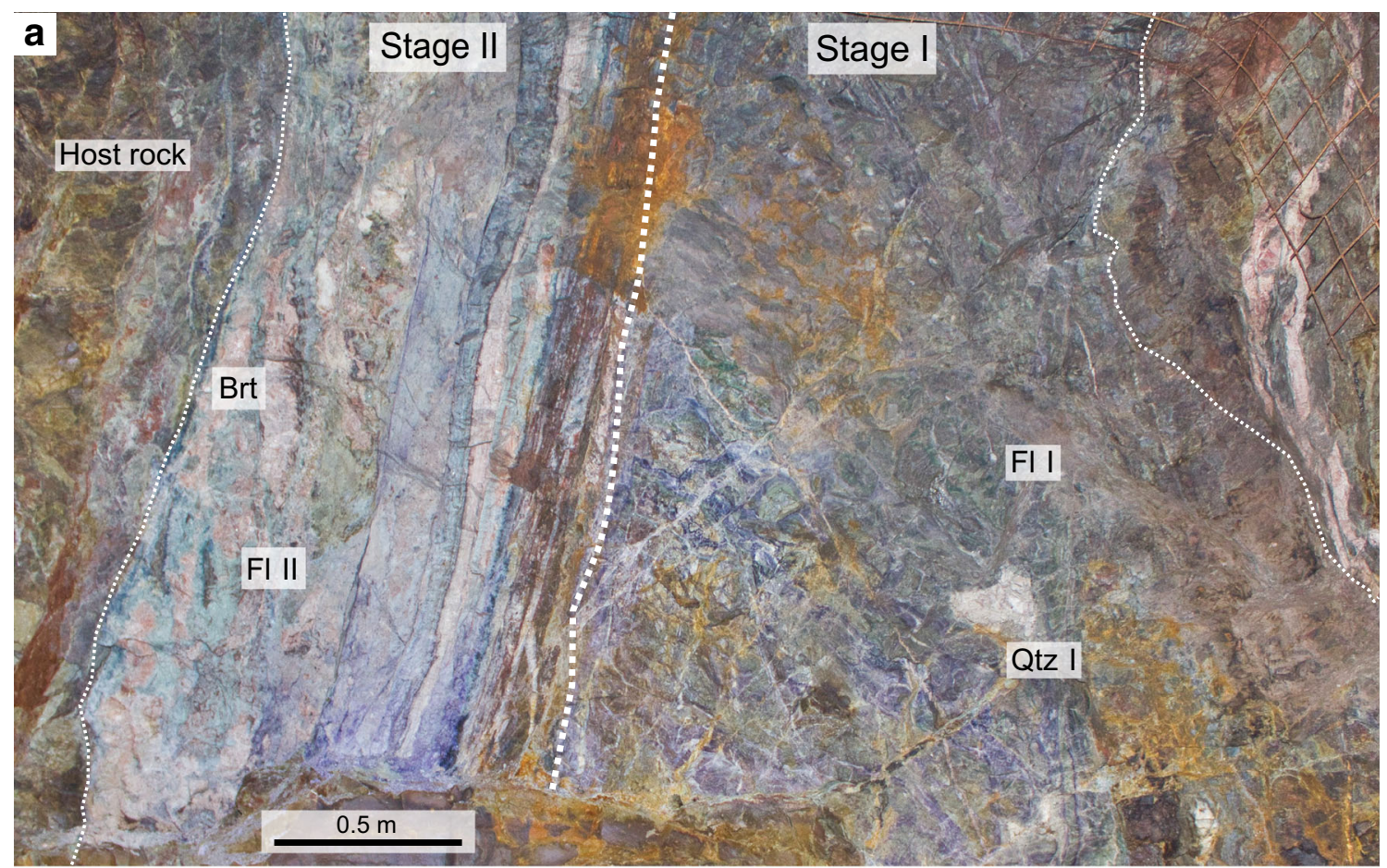

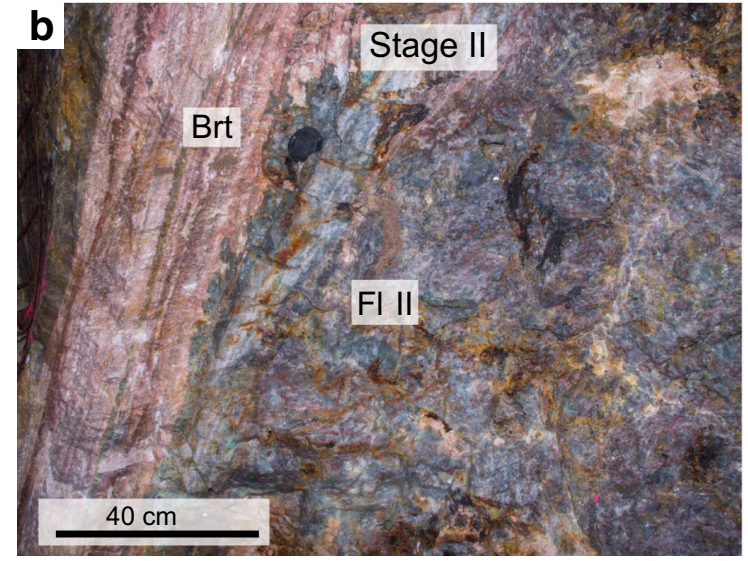

Fig. 2 a Exposure of the main hydrothermal vein at level 6.2 north of the Niederschlag underground mine. Massive Stage I fluorite is cross-cut by banded fluorite and barite of Stage II. b Stage II mineralization composed of banded barite (of) and bluish fluorite (flII). c Green and purple stage I

Underground exposures reveal two distinct stages of fluorite mineralization (Fig. 2a-c): Fluorite I ("flq" after Kuschka 2002 ) is fine-grained, varicoloured and intergrown with quartz, forming colloform bands and complex breccia bodies (Fig. 2c). Intensive alteration (silicification, fluoritization) of vein selvages and intensely altered fragments of host rock within the vein are closely associated with fluorite I mineralization.

Fluorite II cuts across fluorite I and is thus clearly younger (Fig. 2a). Fluorite II ("bafl" after Kuschka 2002) is coarse grained; it forms massive aggregates and/or continuous bands intergrown with variable amounts of barite (Figs. $2 b$ and $3 b$ ). These two minerals are accompanied by quartz and minor

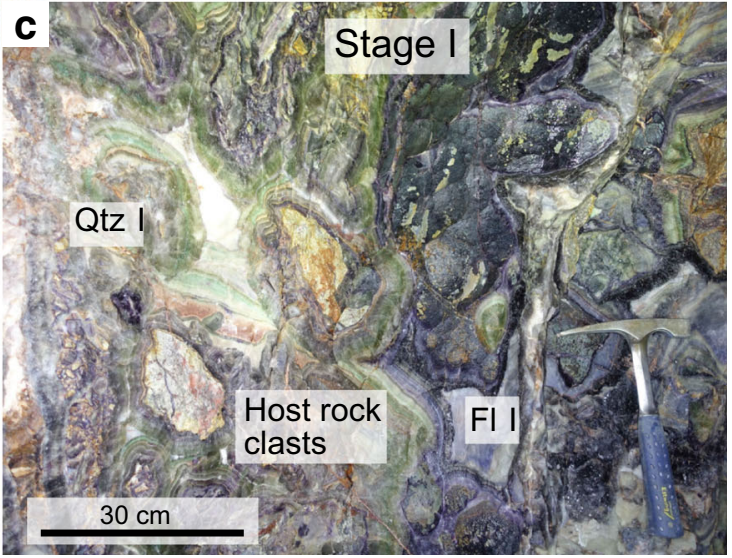

fluorite exhibits banded and colloform textures. Intensively altered (bleached and silicified) host rock clasts are encapsulated by fluorite and quartz (photo taken by: Dr. Uwe Lehmann, Sächsisches Landesamt für Umwelt, Landwirtschaft und Geologie)

tetrahedrite, sphalerite, galena, and chalcopyrite. Whereas Stage I mineralization is reported to be present in approximately equal quantity/thickness and composition throughout the entire explored vertical depth profile of the Niederschlag vein, Stage II mineralization has been reported to show a systematic increase of fluorite and red barite abundance at the expense of white barite with depth (Kuschka 2002). At depths shallower than $200 \mathrm{~m}$ b.g.l., white barite has been reported as the most abundant mineral of Stage II, whereas below this depth, fluorite II becomes more abundant (Kuschka 2002). This distinct change in the mineralogy of the vein-infill roughly coincides with the lithological change from micaschist to gneiss. 

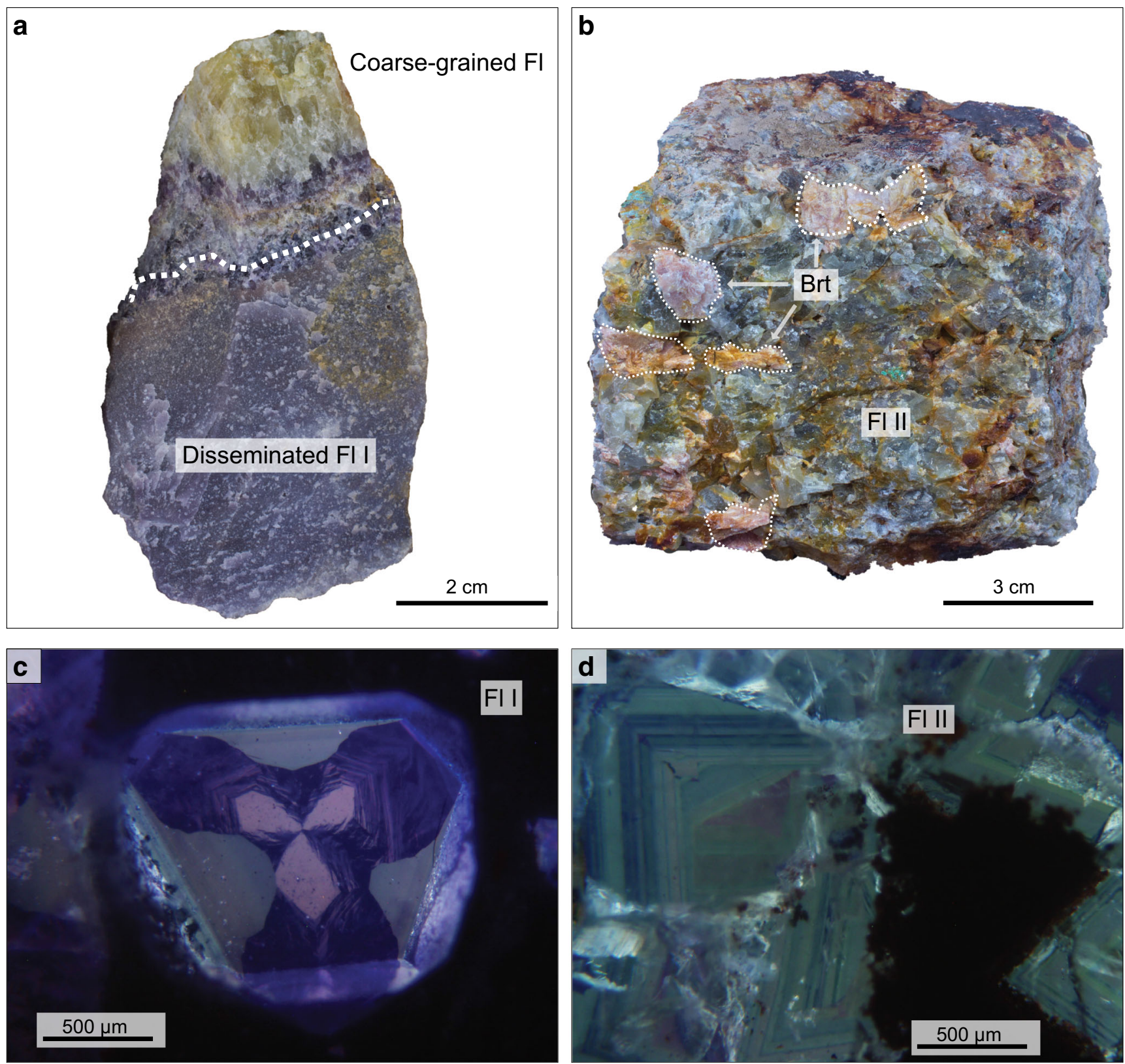

Fig. 3 a Sample MbNds01 showing stage I fluorite mineralization. The hand specimen is composed of coarse grains fluorite and fine-grained fluorite intergrown with quartz (disseminated). b Coarse-grained fluorite II accompanied by reddish barite and minor amounts of secondary

An intense alteration halo that extends between $20 \mathrm{~cm}$ and up to $3 \mathrm{~m}$ into the host rock can be recognized around the Niederschlag vein (Kuschka 2002). Alteration is characterized by strong silicification of the wall rock and is invariably associated with stage I fluorite. In direct contact to the vein, the primary minerals of the host rock may be entirely replaced by quartz, with only minor amounts of kaolinite. Thin marble units show the most intensive alteration, being completely replaced by fluorite and quartz (Kuschka 2002).

Alteration related to Stage II is significantly less pronounced and usually affects only a few millimeters to

malachite (sample SHNdsP8). c Cathodoluminescence image of fluorite I crystal (fl I) showing complex crystal zonation (Sample SHFB-Nds-10). d Cathodoluminescence image of sample SH-FB-Nds-09 showing Fluorite II (fl II) with oscillatory zonation

centimeters of the vein selvage (Kuschka 2002). The alteration assemblage related to Stage II comprises mostly clay minerals, which selectively replaced metamorphic micas.

Cenozoic phonolitic dikes cut the Niederschlag vein, resulting in distinct discoloration and recrystallization of fluorite in the immediate contact ( $\mathrm{cm}$ to a few $\mathrm{dm}$ ) with the dike (Friedländer 2019). This contact metamorphic overprint affects the fluorite only very locally and, therefore, will not be described in detail in this contribution. The phonolite dikes are associated with multi-stadial magmatism related to the Cenozoic Eger Graben rifting (Ulrych et al. 2011) with a 
particular age of $26 \mathrm{Ma}$ for the dike crosscutting the Niederschlag deposit (Walther 2005). The crosscutting relation between fluorite mineralization and the phonolite dykes thus provides a minimum age for fluorite mineralization.

\section{Samples and methodology}

\section{Sampling}

Thirtytwo fluorite samples including both fluorite stages were collected from two exposures in the active underground mine (mine levels 5.1 North at $240 \mathrm{~m}$ b.g.l. and 6.1 level South at $280 \mathrm{~m}$ b.g.l.); from drill cores from the 1970s exploration program that are stored at the Geological Survey of the Free State of Saxony (drill cores 33/74 and 139/36) and from the geoscientific collections of the TU Bergakademie Freiberg. Twentyeight doubly polished thick sections $(\sim 250 \mu \mathrm{m})$ were prepared for petrographic studies, including cathodoluminescence imaging, scanning electron microscopy, and fluid inclusion analyses. Six of these sections were used for LA-ICP-MS analyses. Eight bulk rock samples from various parts of the vein were used for bulk ICP-MS analyses.

\section{Microscopy}

All samples were studied by optical (transmitted and reflected light) microscopy and the investigations were complemented by scanning electron microscopy. Mineral textures were investigated using a Carl Zeiss Axio Imager M1m light microscope (transmitted and reflected light), equipped with an AxioCamMRc5 camera. Backscattered electron images and energy-dispersive X-ray spectra were acquired using a Quanta FEG 600 scanning electron microscope with two Bruker Quantax Dual XFlash 5010 detectors. Measurement conditions were $25 \mathrm{kV}$ acceleration voltage and a beam current of $10 \mathrm{nA}$. Cathodoluminescence imaging (CL) was executed on carbon-coated, polished thin sections using a "hot cathode" CL microscope HC1-LM (cf., Neuser et al. 1995). The system was operated at $14 \mathrm{kV}$ accelerating voltage and a current of $0.2 \mathrm{~mA}$ (current density of about $10 \mu \mathrm{A} / \mathrm{mm}^{2}$ ). Luminescence images were captured "on-line" during CL operations using a Peltier cooled digital video-camera (OLYMPUS DP72).

\section{Microthermometry}

Microthermometric analyses were carried out with a Linkam THSMG600 fluid inclusion stage combined with an Olympus BX53 microscope. The following phase transitions of synthetic standards of $\mathrm{CO}_{2}-\mathrm{H}_{2} \mathrm{O}$ and $\mathrm{H}_{2} \mathrm{O}$ inclusions were used for calibration: Tm $\left(\mathrm{CO}_{2}\right), \mathrm{Tm}$ (ice) and Th. Standard material was analyzed daily before each measurement campaign to check for potential calibration drifts. Petrographic descriptions of fluid inclusion assemblages (FIAs) were classified as primary (p), secondary (s), pseudo-secondary (ps), or isolated (i) fluid inclusions (van den Kerkhof and Hein 2001). Liquidvapor ratios were estimated by image analysis and are given as $L_{x} V_{y}(x+y=1)$. To ensure reproducibility, each phase transition was measured three times. Phase changes were measured with a heating rate of $1{ }^{\circ} \mathrm{C} / \mathrm{min}$, resulting in instrumental uncertainties of $\pm 0.2{ }^{\circ} \mathrm{C}$ for melting temperatures and $\pm 1{ }^{\circ} \mathrm{C}$ for homogenization temperatures. Fluid inclusions (FIs) with signs of post- entrapment alteration (e.g., necking down) or evidence of metastable behavior (e.g., absence of hydrohalite for FIs with $\mathrm{Te}$ of $-52{ }^{\circ} \mathrm{C}$ ) were excluded from the data set. Based on the presence of hydrohalite and final ice melting temperatures, salinities and molar $\mathrm{Na} /(\mathrm{Ca}+\mathrm{Na})$ ratios were calculated using the spreadsheet provided by SteeleMacInnis et al. (2011) for the $\mathrm{Na}-\mathrm{Ca}-\mathrm{Cl}-\mathrm{H}_{2} \mathrm{O}$ system.

\section{Laser ablation inductively-coupled mass- spectrometry}

LA-ICP-MS analyses of fluorite were carried out on six polished thin sections at the GeoForschungsZentrumPotsdam with a Geolas Compex Pro $193 \mathrm{~nm}$ excimer laser coupled to a Thermo iCAP TQ mass spectrometer. NIST 610 served as an external standard, while ideal stoichiometric $\mathrm{Ca}$ content was used as internal standard for ${ }^{44} \mathrm{Ca}$ (Gagnon et al. 2003). A spot size of $44 \mu \mathrm{m}$ with a repetition rate of $5 \mathrm{~Hz}$ and laser energy density of $5 \mathrm{~J} \mathrm{~cm}^{-2}$ was set for measurements. Data were processed using the trace elements IS data reduction scheme (Woodhead et al. 2007) in iolite 3.63 (Paton et al. 2011). The following isotopes were measured with their repespective average detection limits given in brackets: ${ }^{7} \mathrm{Li}$ $(4.38 \mathrm{mg} / \mathrm{kg}),{ }^{23} \mathrm{Na}(91.77 \mathrm{mg} / \mathrm{kg}),{ }^{24} \mathrm{Mg}(2.84 \mathrm{mg} / \mathrm{kg}),{ }^{39} \mathrm{~K}$ $(26.34 \mathrm{mg} / \mathrm{kg}),{ }^{45} \mathrm{Sc}(3.28 \mathrm{mg} / \mathrm{kg}),{ }^{55} \mathrm{Mn}(8.71 \mathrm{mg} / \mathrm{kg}){ }^{57} \mathrm{Fe}$ $(40.15 \mathrm{mg} / \mathrm{kg}),{ }^{66} \mathrm{Zn}(7.37 \mathrm{mg} / \mathrm{kg}),{ }^{71} \mathrm{Ga}(0.36 \mathrm{mg} / \mathrm{kg}),{ }^{85} \mathrm{Rb}$ $(0.54 \mathrm{mg} / \mathrm{kg}),{ }^{88} \mathrm{Sr}(0.08 \mathrm{mg} / \mathrm{kg}),{ }^{89} \mathrm{Y}(0.13 \mathrm{mg} / \mathrm{kg}),{ }^{137} \mathrm{Ba}$ $(0.32 \mathrm{mg} / \mathrm{kg}),{ }^{139} \mathrm{La}(0.52 \mathrm{mg} / \mathrm{kg}),{ }^{140} \mathrm{Ce}(0.56 \mathrm{mg} / \mathrm{kg}),{ }^{141} \mathrm{Pr}$ $(0.14 \mathrm{mg} / \mathrm{kg}),{ }^{146} \mathrm{Nd}(0.38 \mathrm{mg} / \mathrm{kg}),{ }^{147} \mathrm{Sm}(0.39 \mathrm{mg} / \mathrm{kg}),{ }^{153} \mathrm{Eu}$ $(0.04 \mathrm{mg} / \mathrm{kg}),{ }^{157} \mathrm{Gd}(0.21 \mathrm{mg} / \mathrm{kg}),{ }^{159} \mathrm{~Tb}(0.03 \mathrm{mg} / \mathrm{kg}),{ }^{153} \mathrm{Dy}$ $(0.10 \mathrm{mg} / \mathrm{kg}),{ }^{165} \mathrm{Ho}(0.02 \mathrm{mg} / \mathrm{kg}),{ }^{166} \mathrm{Er}(0.01 \mathrm{mg} / \mathrm{kg}),{ }^{169} \mathrm{Tm}$ $(0.02 \mathrm{mg} / \mathrm{kg}),{ }^{172} \mathrm{Yb}(0.07 \mathrm{mg} / \mathrm{kg}),{ }^{175} \mathrm{Lu}(0.02 \mathrm{mg} / \mathrm{kg}),{ }^{208} \mathrm{~Pb}$ $(0.27 \mathrm{mg} / \mathrm{kg})$.

\section{Solution ICP-MS}

Handpicked fluorite separates (over 99\% fluorite) were rinsed with deionized water, dried and powdered in an agate mortar in a planetary mill at the Helmholtz Institute Freiberg for Resource Technology to a grain size smaller than $63 \mu \mathrm{m}$. The powders were acid-digested according to the protocol of Kraemer et al. (2019) with a mixture of suprapure $\mathrm{HF}^{-\mathrm{HClO}_{4}}$ in a Picotrace DAS digestion unit and analyzed with a Perkin- 
Elmer Nexion 350x ICP-MS at the Geochemistry Laboratory of Jacobs University Bremen. REY concentrations are normalized to European Shale (EUS) of Bau et al. (2018). Normalized data is indicated with the subscript SN (shalenormalized).

\section{Results}

The following sections summarize macroscopic and microscopic petrographic observations of both fluorite stages as well as fluid inclusion and trace-element data. The complete background data set is provided in the electronic supplement (Table ES1, ES2, ES3, and ES4).

\section{Macroscopic and microscopic observations}

The two underground exposures that were available for this study reflect full horizontal profiles from the host rock through the Niederschlag vein with a width of about $4 \mathrm{~m}$. The contact of the host rock and vein is marked by a distinct and intense alteration halo, which extends about $3 \mathrm{~m}$ wide into the host rock on both sides of the vein. Consistent with observation reported by Kuschka (2002), host rock alteration is characterized by strong silification. The contact between the altered host rock and Stage I mineralization is typically sharp, but intense brecciation of the host rock is common. At the selvage of the vein, fluorite I is intimately intergrown with finegrained quartz, which together form mineralization Stage I. No other minerals were observed for Stage I; however, perimorphs of quartz and fluorite with rhombohedral outlines are common and may represent former carbonates. Stage I comprises multiple generations of thin $(1 \mathrm{~mm}$ to $1 \mathrm{~cm})$, irregularly shaped collomorphous bands of fluorite and quartz/ chalcedony, which all together form masses that may reach up to several meters in thickness (Fig. 2c). Crystal sizes range from sub-mm to centimeters. Fluorite within Stage I forms continuous layers but may also occur as disseminated euhedral fluorite grains enclosed by fine-grained quartz (Fig. 3a-b). Massive fluorite domains exhibit a distinct alternating layering of purple and green colored fluorite. Less commonly, pale yellow to colorless fluorite can be observed. Mostly green and purple fluorite layers exhibit botryoidal textures, which are composed of individual prismatic fluorite grains. These layered masses are often brecciated and recemented by younger generatins of layered purple and green fluorite. Complex sectoral zoning is characteristic of purple fluorite (Fig. 3c). The sector zonation ranges from deep blue to yellow-blue colors, indicating primary growth features. In contrast, massive green fluorite is characterized by blue luminescence color without distinct sectoral zoning. Chalcedony with disseminated hematite fills microfractures in fluorite I; this marks the end of mineralization Stage I.
Minerals of the second fluorite stage (fluorite II) cuts Stage I mineralization. Coarse-grained fluorite II crystals are up to several centimeters in size and show cubic crystal shapes. Fluorite II is commonly of pale bluish color. Less frequently, yellowish to white-colored colors are observed. Fluorite II is distinctly zoned, with massive cores and rims that display oscillatory zoning (Fig. 3d). Similar zoning patterns have been frequently reported in studies from other fluorite vein deposits e.g., (Schwinn and Markl 2005).

Fluorite II is accompanied by barite and minor amounts of base metal sulfides and quartz (Fig. 3a-b). Red-colored barite (with fine-grained hematite) is present as aggregates, up to $5 \mathrm{~cm}$ in size, or forms discrete bands of up to several centimeters in thickness, which are intergrown with variable amounts of fluorite II. Locally, barite is pseudomorphously replaced by quartz (Burisch et al. 2017). The intensity of this replacement process appears to be high, where barite is entirely encapsulated by fluorite II. Millimeter to a few centimeter-sized, large aggregates of sulfides (mostly chalcopyrite, galena, and tetrahedrite) occur in variable abundances associated with fluorite II and quartz.

\section{Fluid inclusion petrography}

Suitable fluid inclusions for microthermometric analyses were recognized in fluorite of Stages I and II. Fluorite and quartz of the first mineralization stage yield only few primary fluid inclusions suitable for microthermometry. There are zones in fluorite I crystals that are strongly enriched in fluid inclusions; the inclusions do show heterogeneous fluid inclusion assemblages with unsystematic behavior of the measured fluid inclusions. CL imaging revealed a very fine-grained texture of these inclusion-rich fluorite grains (Fig. 4c-d), strongly suggesting that these fluid inclusions (FIs) are related to recrystallization of fluorite I and thus record no primary information (Sander and Black 1988) and have therefore been rigorously excluded from the data set. Fluid inclusions that can unambiguously be identified as primary occur as clusters in massive purple fluorite I and have diameters that range from 20 to $30 \mu \mathrm{m}$. Secondary inclusions are widespread in fluorite I. They are mostly present along discrete micro-fractures and do propagate across grain boundaries.

Fluorite II, in constrast, contains abundant fluid inclusion assemblages of primary, pseudo-secondary, and secondary origin with inclusions up to $100 \mu \mathrm{m}$ in size (Fig. 4c-d). The inclusions mostly occur in clusters of primary origin or, rarely, aligned along growth zones. Two-phase liquid-vapor inclusions are dominant, though three-phase liquid-vapor-solid inclusions can also occasionally be observed (Fig. 4d). The solid phases are irregularly shaped and do not melt upon heating. Some inclusions show evidence for post-entrapment modification; these were excluded from the data set. 

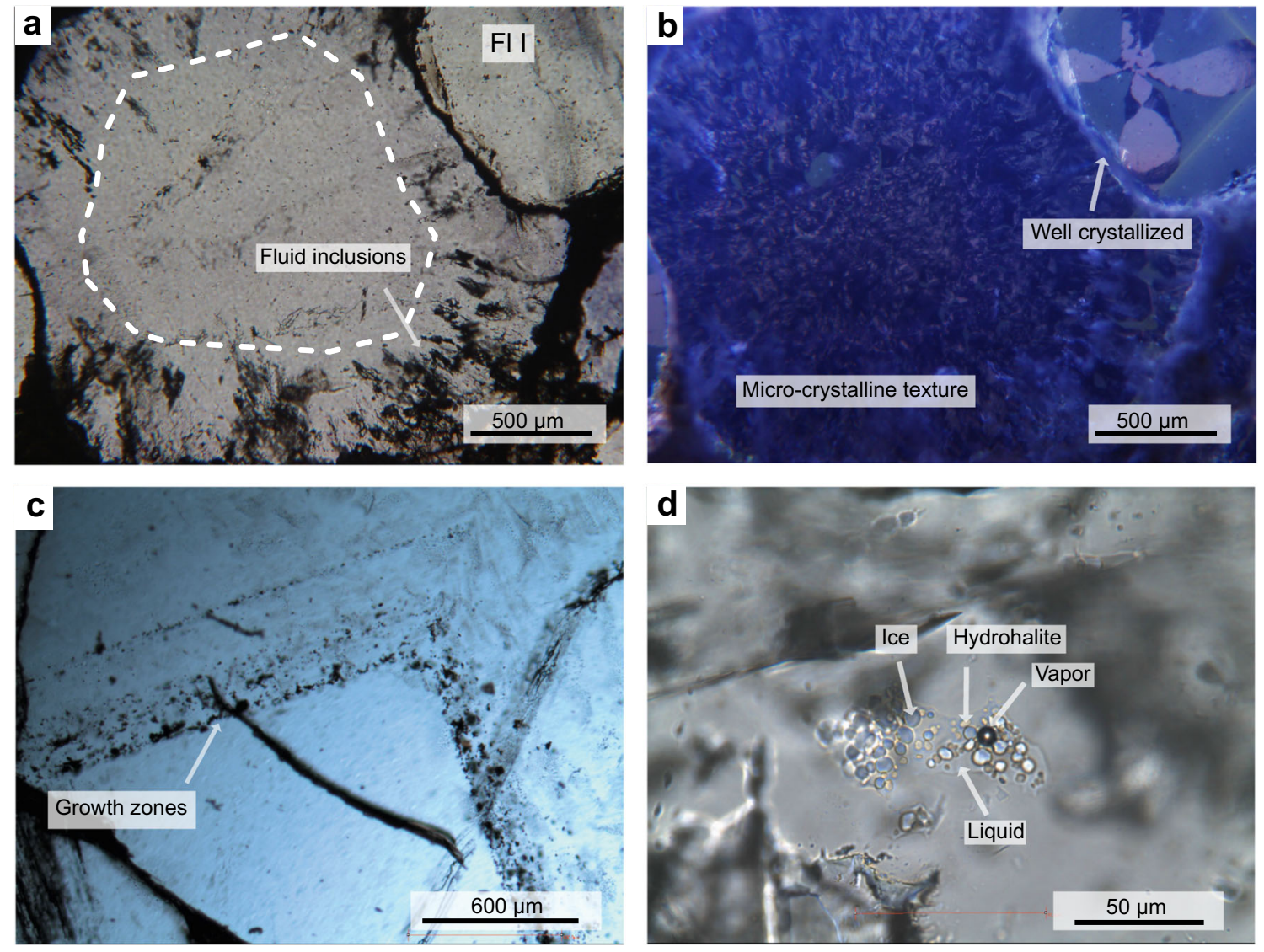

Fig. 4 a Transmitted light microphotograph of sample SH-FB-Nds-10 showing euhedral to subhedral fluorite I crystals. The core of the larger fluorite crystal is free of fluid inclusion, whereas its rim contains numerous fluid inclusions. b Cathodoluminescence microphotograph of the section showed in A, reveals the micro-crystalline texture of the larger fluorite grain, while the smaller euhedral grain (upper right) is well-

\section{Microthermometry}

Microthermometric analyses of 34 primary inclusions in 9 assemblages hosted by fluorite I show eutectic temperatures (Te) around $-52{ }^{\circ} \mathrm{C}$, which indicates that the fluid inclusions can best be described in the $\mathrm{NaCl}-\mathrm{CaCl}_{2}-\mathrm{H}_{2} \mathrm{O}$ system. Hydrohalite was detected in all analyzed inclusions; it is observed to melt invariably before ice upon heating. Hydrohalite melting temperatures $(\mathrm{Tm}(\mathrm{hh}))$ range between $-21.2{ }^{\circ} \mathrm{C}$ and $-25.6{ }^{\circ} \mathrm{C}$. Final ice melting temperatures (Tm (ice)) are between $-4.4{ }^{\circ} \mathrm{C}$ and $-15{ }^{\circ} \mathrm{C}$. Corresponding total salinities range from 7.1 to $19.6 \%$ eq. $\mathrm{w}\left(\mathrm{NaCl}+\mathrm{CaCl}_{2}\right)$ with the $\mathrm{Na} /$ $(\mathrm{Na}+\mathrm{Ca}$ ) ratio ranging from 1 to 0.52 (Figs. 5b, 6a-c). The variation of total salinities and $\mathrm{Na} / \mathrm{Na}+\mathrm{Ca})$ ratios within fluid inclusion assemblages is relatively small, namely, $<2 \%$ eq. w $\left(\mathrm{NaCl}+\mathrm{CaCl}_{2}\right)$ and $<0.3$, respectively (Table 1$)$.

Microthermometric data of 124 individual fluid inclusions in 25 assemblages related to fluorite II (Fig. 4) show eutectic temperatures of around $-52{ }^{\circ} \mathrm{C}$, which again indicates that they can best be described as $\mathrm{NaCl}-\mathrm{CaCl}_{2}-\mathrm{H}_{2} \mathrm{O}$-fluids. Calculated salinities vary between 19 and $27 \%$ eq. w

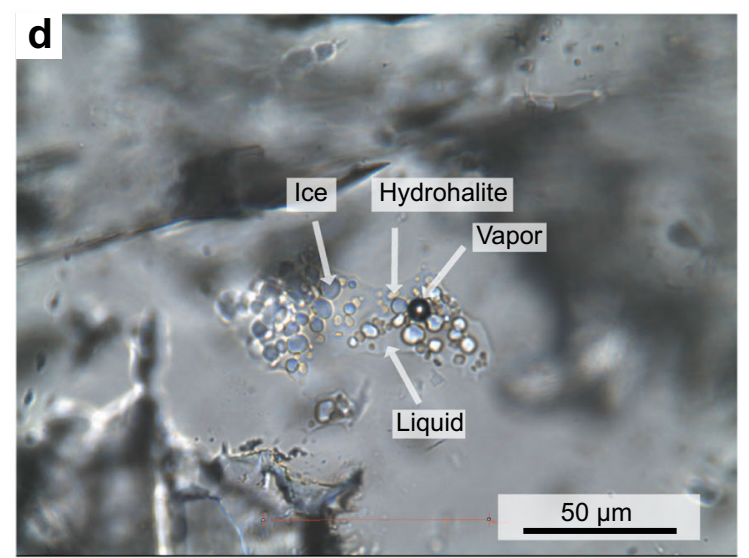

crystalized. c Transmitted light microphotograph of sample SHNdsP8A showing a euhedral fluorite II crystal with growth zones that host numerous primary fluid inclusions as well as fine-grained Fe-Mn oxides. d Transmitted light microphotograph of sample SHNds-P8C showing a primary fluid inclusion containing ice, hydrohalite, liquid, and vapor at $30{ }^{\circ} \mathrm{C}$

$\left(\mathrm{NaCl}+\mathrm{CaCl}_{2}\right)$ (Fig. 6a-c); this variability is observed not only between but also within fluid inclusion assemblages (FIA). Average $\mathrm{Na} /(\mathrm{Ca}+\mathrm{Na})$ ratios of FIAs vary between 0.43 and 0.82 , again very similar to the variability documented within individual FIAs (0.41-0.73). There is no obvious correlation between $\mathrm{Na} /(\mathrm{Na}+\mathrm{Ca})$-ratio and temperature or total salinity (Table 2). Some of the primary FI contain unknown greenish, prismatic solid inclusions; these do not show dissolution nor any recognizable volume change upon heating to $200{ }^{\circ} \mathrm{C}$. Fluid inclusions containing such solid inclusions are marked by more variable microthermometric results than fluid inclusions without solid inclusions.

\section{REY geochemistry}

REY data are reported here for three samples of fluorite I and five samples of fluorite II that were analyzed as mineral separates using ICP-MS. These results are reported together with mineral chemical data for the two fluorite generations obtained with LA-ICP-MS on three thick sections containing fluorite I, and three thick sections containing fluorite II. Results 
Table 1 Fluid inclusion microthermometry data of fluorite I and II of the Niederschlag fluorite deposit summarized as fluid inclusion assemblages

\begin{tabular}{|c|c|c|c|c|c|c|c|c|c|c|c|}
\hline Assemblage code & Stage & $n$ & $\begin{array}{l}\text { Avg. Th } \\
\text { in }{ }^{\circ} \mathrm{C}\end{array}$ & $\begin{array}{l}\text { Min. Th } \\
\text { in }{ }^{\circ} \mathrm{C}\end{array}$ & $\begin{array}{l}\text { Max. Th } \\
\text { in }{ }^{\circ} \mathrm{C}\end{array}$ & $\begin{array}{l}\text { Avg. } \\
\text { salinity }\end{array}$ & $\begin{array}{l}\text { Min. } \\
\text { salinity }\end{array}$ & $\begin{array}{l}\text { Max. } \\
\text { salinity }\end{array}$ & $\begin{array}{l}\text { Avg. } \mathrm{Na}-\mathrm{Ca}- \\
\text { ratio }\end{array}$ & $\begin{array}{l}\text { Min. } \mathrm{Na}-\mathrm{Ca}- \\
\text { ratio }\end{array}$ & $\begin{array}{l}\text { Max. Na- } \\
\text { Ca-ratio }\end{array}$ \\
\hline MBNds01aCFlclustera1 & I & 3 & 157 & 156 & 159 & 7.12 & 7.10 & 7.13 & 0.73 & 0.71 & 0.75 \\
\hline MbNds01aCFlclusterc1 & I & 3 & 170 & 170 & 171 & 18.65 & 13.10 & 13.20 & 0.84 & 0.73 & 1.00 \\
\hline MbNds01aGFlclusterd 1 & I & 3 & 162 & 160 & 164 & 18.61 & 18.61 & 18.61 & 0.65 & 0.81 & 0.81 \\
\hline MbNds01aCFlclusterc2 & I & 3 & 170 & 170 & 171 & 13.17 & 13.09 & 13.20 & 0.82 & 0.73 & 1.00 \\
\hline MbNds01aCFlclusterd 1 & I & 3 & 177 & 176 & 180 & 9.65 & 9.57 & 9.82 & 0.82 & 0.73 & 1.00 \\
\hline MbNds01aCFlclustere1 & I & 4 & 163 & 161 & 166 & 11.18 & 11.14 & 11.20 & 0.64 & 0.62 & 0.72 \\
\hline MbNds01aCFlclusterg1 & I & 4 & 158 & 156 & 160 & 18.01 & 17.47 & 19.61 & 0.62 & 0.65 & 0.65 \\
\hline MbNds01aGFlclusterc1 & I & 4 & 157 & 150 & 163 & 16.82 & 16.82 & 16.82 & 0.52 & 0.52 & 0.52 \\
\hline MbNds01aGFlclusterd1 & I & 3 & 162 & 160 & 164 & 18.61 & 18.61 & 18.61 & 0.81 & 0.81 & 0.81 \\
\hline SHNdsP8-CBFIP2 & II & 4 & 105 & 96 & 112 & 21.48 & 20.85 & 23.34 & 0.68 & 0.63 & 0.78 \\
\hline SHNdsP8-AAFIP1 & II & 5 & 99 & 88 & 110 & 22.98 & 19.66 & 25.37 & 0.66 & 0.60 & 0.79 \\
\hline SHNdsP7-BGF1P11 & II & 5 & 98 & 86 & 107 & 19.71 & 19.14 & 20.16 & 0.61 & 0.57 & 0.65 \\
\hline SHNdsP8-DAFIP11 & II & 5 & 89 & 87 & 93 & 26.17 & 25.45 & 27.37 & 0.63 & 0.41 & 0.73 \\
\hline SHNdsP7-EFFlp11 & II & 4 & 104 & 101 & 106 & 24.72 & 24.69 & 25.69 & 0.79 & 0.79 & 0.79 \\
\hline SHNdsP7-EhFlp21 & II & 4 & 108 & 90 & 111 & 21.22 & 18.95 & 24.98 & 0.82 & 0.59 & 0.98 \\
\hline SHNdsP8AaFlp31 & II & 4 & 103 & 104 & 117 & 20.68 & 19.22 & 24.98 & 0.59 & 0.59 & 0.74 \\
\hline SHNdsP7-DEFlp31 & II & 4 & 113 & 109 & 117 & 20.45 & 20.32 & 20.51 & 0.73 & 0.73 & 0.74 \\
\hline SHNdsP7-DEFlp41 & II & 6 & 107 & 101 & 115 & 21.14 & 20.24 & 22.14 & 0.71 & 0.69 & 0.75 \\
\hline SHNdsP7-BEFlp31 & II & 5 & 102 & 92 & 110 & 21.15 & 20.30 & 22.44 & 0.69 & 0.69 & 0.69 \\
\hline SHNdsP8-DAFlp21 & II & 5 & 103 & 93 & 107 & 20.68 & 20.04 & 21.05 & 0.56 & 0.56 & 0.56 \\
\hline SHNdsP8-DAFlp31 & II & 5 & 94 & 83 & 106 & 20.00 & 19.07 & 20.51 & 0.43 & 0.42 & 0.44 \\
\hline SHNdsP7-AFlps11 & II & 3 & 123 & 116 & 130 & 20.60 & 19.27 & 22.20 & 0.70 & 0.63 & 0.80 \\
\hline SHNdsP7-AFlps 21 & II & 5 & 91 & 82 & 96 & 25.64 & 25.55 & 26.45 & 0.74 & 0.61 & 0.80 \\
\hline SHFB-Nds-05bFlbps5 & II & 5 & 96 & 92 & 101 & 26.42 & 20.14 & 26.45 & 0.63 & 0.43 & 0.72 \\
\hline SHFB-Nds-03Fla1 & II & 4 & 113 & 107 & 117 & 24.68 & 24.68 & 24.68 & 0.69 & 0.69 & 0.69 \\
\hline SHFB-Nds-03Fla1 & II & 4 & 124 & 121 & 126 & 19.97 & 19.60 & 20.14 & 0.44 & 0.43 & 0.45 \\
\hline SHFB-Nds-03Flb1 & II & 3 & 103 & 98 & 113 & 19.69 & 19.69 & 19.69 & 0.53 & 0.53 & 0.53 \\
\hline SHFB-Nds-03Fla1 & II & 4 & 110 & 104 & 115 & 21.49 & 21.36 & 21.53 & 0.46 & 0.39 & 0.59 \\
\hline SHFB-Nds-03Flp11 & II & 6 & 111 & 108 & 113 & 21.50 & 21.50 & 21.50 & 0.82 & 0.82 & 0.82 \\
\hline SHFB-Nds-03Flp21 & II & 5 & 112 & 108 & 120 & 21.08 & 21.08 & 21.08 & 0.75 & 0.75 & 0.75 \\
\hline SHFB-Nds-03Flp11 & II & 5 & 110 & 108 & 113 & 21.18 & 20.41 & 21.59 & 0.72 & 0.63 & 0.80 \\
\hline SHFB-Nds-03Flp21 & II & 7 & 112 & 112 & 112 & 20.75 & 20.75 & 20.75 & 0.79 & 0.79 & 0.79 \\
\hline SHFB-Nds-03Flp31 & II & 6 & 121 & 117 & 124 & 21.77 & 21.77 & 21.77 & 0.70 & 0.70 & 0.70 \\
\hline SHFB-Nds-03Flp11 & II & 6 & 97 & 94 & 105 & 21.16 & 20.87 & 21.49 & 0.57 & 0.56 & 0.57 \\
\hline SHFB-Nds-03Flp1 1 & II & 5 & 96 & 90 & 101 & 20.88 & 20.42 & 21.24 & 0.61 & 0.56 & 0.63 \\
\hline
\end{tabular}

obtained by both analytical approaches are consistent with one anotherr (Fig. 7).

Fluorite I has relatively low absolute REY concentrations with values ranging from 82.0 to $124.0 \mathrm{mg} / \mathrm{kg}$ total $\mathrm{REY}$ content (Fig. 7a) in the bulk samples. Shale-normalized REY $\left(\mathrm{REY}_{\mathrm{SN}}\right)$ patterns show conspicuously flat trends. Small negative Ce and positive $\mathrm{Y}$ anomalies can be observed. Despite their different macroscopic appearance, green and purple fluorite I varieties show the same REY ${ }_{S N}$ patterns. In situ LA-ICP-MS analyses of fluorite I show more substantial variations in REY compositions between individual laser spots (Fig. 7a). Particularly, LREE vary considerably even within single crystals (Fig. 7a).

Stage II fluorite, in contrast, has distinctly higher total REY concentrations, ranging from 177.9 to $272.0 \mathrm{mg} / \mathrm{kg}$. The $\mathrm{REY}_{\mathrm{SN}}$ patterns of Stage II fluorite are characterized by depletion of LREE and HREE, while MREE are distinctly enriched, resulting in a bell-shaped $\mathrm{REY}_{\mathrm{SN}}$ pattern (Fig. 7b). Individual LA-ICP-MS analyses of Stage II fluorite show relatively uniform $\mathrm{REY}_{\mathrm{SN}}$ patterns. Yttrium shows a positive anomaly, whereas the LREE are systematically depleted. 


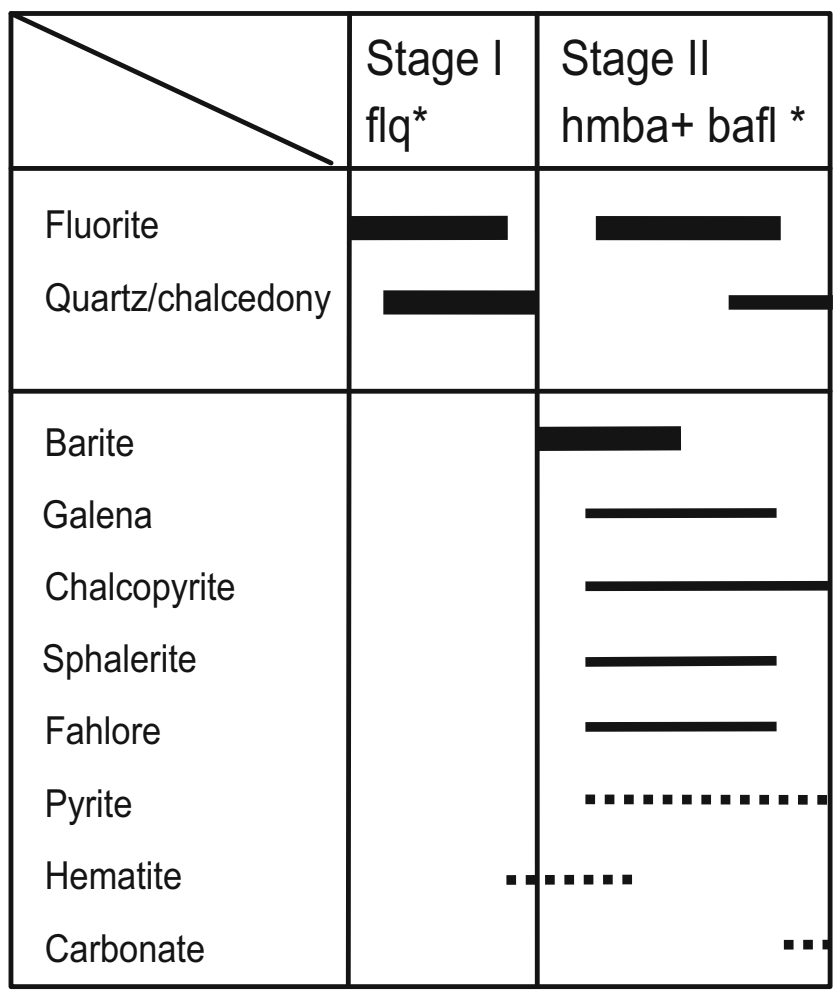

Fig. 5 Paragenetic sequence of stage I and II (*classification after (Kuschka 2002)) mineralization at the Niederschlag deposit

A distinct positive $\mathrm{Y}_{\mathrm{SN}}$ anomaly is evident in both stages, but the concentration of Y in Stage II fluorite is about an order of magnitude higher than in Stage I fluorite. All fluorite samples investigated in this study show a fractionation of $Y$ from Ho and comprise similar $\mathrm{Y} / \mathrm{Ho}$ fractionation ratios, ranging from 53.9-72.3 in fluorite I and 53.4-73.2 in fluorite II.

\section{Discussion}

In the following, we discuss petrographic, microthermometric, and geochemical data of the two different fluorite generations to constrain the nature of the associated fluids and the ore-forming processes. In the absence of geochronological evidence, we will only briefly speculate on possible geodynamic settings of the two mineralization stages.

\section{Nature of hydrothermal fluids}

Fluid inclusion evidence suggests low temperatures of formation $\left(140\right.$ to $\left.180{ }^{\circ} \mathrm{C}\right)$ for the fluorite-quartz assemblage of Stage I. Fluorite I was precipitated from a low to medium saline Na-Ca-Cl- $\mathrm{H}_{2} \mathrm{O}$-fluid. The absence of S-bearing minerals (neither sulfides nor sulfates) in this stage is rather unusual (Burisch et al. 2017; Burisch et al. 2018; Keim et al. 2018; Kraemer et al. 2019) and indicates that the fluids that were involved in the formation of the fluorite mineralization were nominally S-free. Furthermore, intense host rock alteration associated with Stage I suggests a high reactivity of the fluid towards the silicate-dominated host rock (gneiss, mica schist). Silicification, weak kaolinization, as well as the replacement of presumably early carbonates and marble horizons are all indicative of low $\mathrm{pH}$ fluids.

Fluid inclusion assemblages in fluorite II, in contrast, yield even lower temperatures $\left(80-120^{\circ} \mathrm{C}\right)$, but higher salinities $\left(18-27 \%\right.$ eq. $\left.\mathrm{w}\left(\mathrm{NaCl}+\mathrm{CaCl}_{2}\right)\right)$ that can also be bestdescribed in the Na-Ca-Cl- $\mathrm{H}_{2} \mathrm{O}$ system (Fig. 6c). Fluorite II is invariably associated with sulfides and substantial quantities of barite, indicating that both reduced and oxidized sulfur as well as $\mathrm{Pb}, \mathrm{Zn}, \mathrm{Cu}$, and $\mathrm{Ba}$ were available during ore formation. Host rock alteration related to this stage is very subordinate at best, macroscopically often not visible at all. This may suggest that the hydrothermal fluid responsible for fluorite IIbarite mineralization was non-reactive or close to equilibrium with the silicate host rock. Similar characteristics have been reported from many fluorite vein deposits in Central Europe. They have been interpreted as mixtures of a deep-seated basement brine with certain proportions of a saline sedimentary fluid (Bauer et al. 2019; Boiron et al. 2010; Fusswinkel et al. 2013; Gleeson et al. 2001).

\section{REY sources and water-rock interaction}

Although REY concentrations obtained for individual spots of in situ LA-ICP-MS analyses are marked by substantial variations (especially for fluorite I), average values are consistent with bulk ICP-MS analyses of fluorite concentrates. Therefore, the fluorite compositions (Fig. 7a-b) are used as a reliable indicator for the REY systematics inherent to fluorite I and fluorite II stages. Although the REY systematics of the two fluorite stages are very distinct, they share a positive $\mathrm{Y}_{\mathrm{SN}}$ anomaly. This $\mathrm{Y}_{\mathrm{SN}}$ anomaly is a common feature of many fluorite occurrences worldwide, such as the ones from the Pennine Ore field (Great Britain), Harz mountains (Germany) or the Schwarzwald (Germany) (Fig. 8b) (Bau and Dulski 1995; Kraemer et al. 2019; Walter et al. 2018b). It is thought to reflect the the lower stability of $\mathrm{YF}^{+}{ }_{2}$-fluoride complexes relative to $\mathrm{HoF}^{2+}$-fluoride complexes in hydrothermal solutions (Loges et al. 2013).

The overall flat $\mathrm{REY}_{\mathrm{SN}}$ pattern of fluorite I is very unusual and has not been reported from other fluorite vein deposits in Central Europe. It also lacks similarity to fluorite associated with greisen and skarn deposits in the Erzgebirge that formed at higher temperatures (Korges et al. 2019; Lefebvre et al. 2019; Wolff et al. 2015b). The flat pattern is, however, very similar to the REE $\mathrm{SN}_{\mathrm{S}}$ patterns of the unaltered host rock (Mingram et al. 2004; Tichomirowa et al. 2012) (Fig. 8a). Even the small negative Ce anomaly of fluorite I may have been derived from the host rocks (Moeller and Bau 1993). These observations may be used to suggest that intensive 

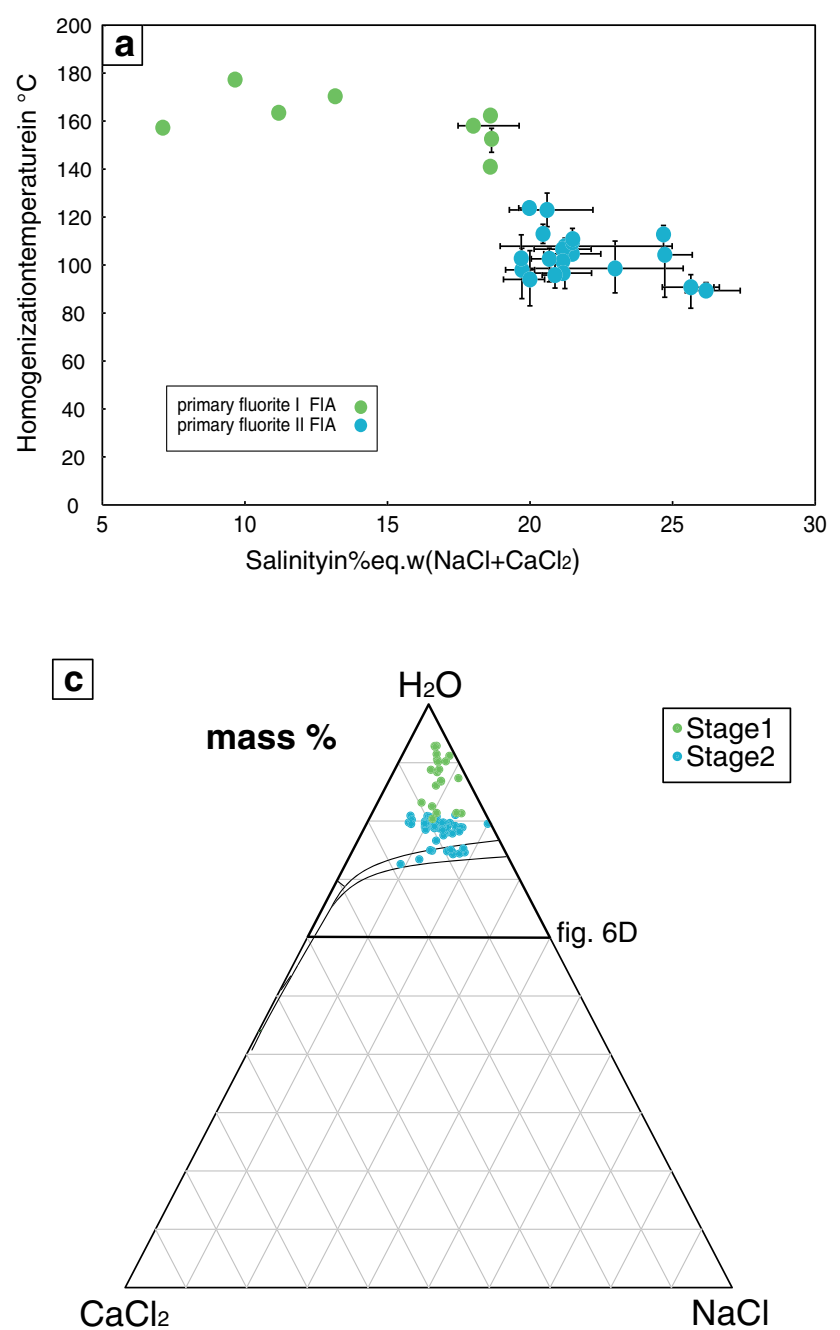

Fig. 6 a Salinity in \% eq. $\mathrm{w}\left(\mathrm{NaCl}+\mathrm{CaCl}_{2}\right)$ versus homogenization temperature and $\mathrm{Na} /(\mathrm{Na}+\mathrm{Ca})$ versus homogenization temperature $\mathbf{b}$ comprising 161 analyses of primary fluid inclusions summarized as fluid inclusion assemblages (FIAs). Data points indicate the average value and the $\mathrm{X}$-Y-bars the range of each fluid inclusion assemblage.

host-rock alteration associated with Stage I buffered the REY budget of the hydrothermal fluid responsible for the formation of fluorite I. Heterogeneous fluid inclusions (which were not included in the microthermometric data set) and longprismatic habit of particularly green fluorite layers of stage I further indicate that precipitation of fluorite I was relatively fast and far from equilibrium, thus inhibiting mineral-specific fractionation of REYs.

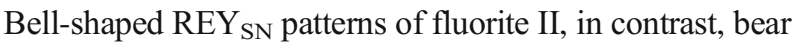
close resemblance to many other low-temperature fluorite vein deposits across Europe (Bau and Dulski 1995; Kraemer et al. 2019; Nadoll et al. 2019; Sánchez et al. 2010; Schwinn and Markl 2005). REY ${ }_{\mathrm{SN}}$ patterns - together with the previously discussed analogies in terms of fluid composition and mineral paragenesis - provide strong support that Stage II fluorite-barite mineralization at the Niederschlag deposit was

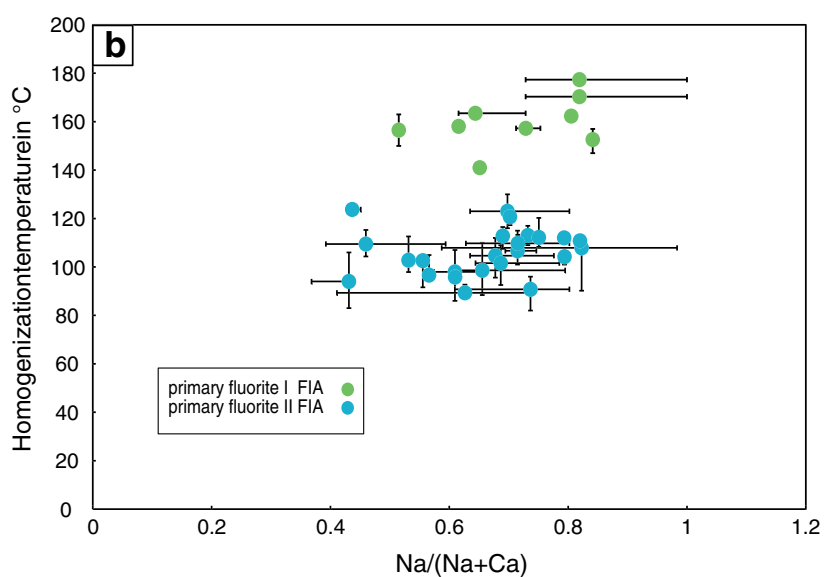

d

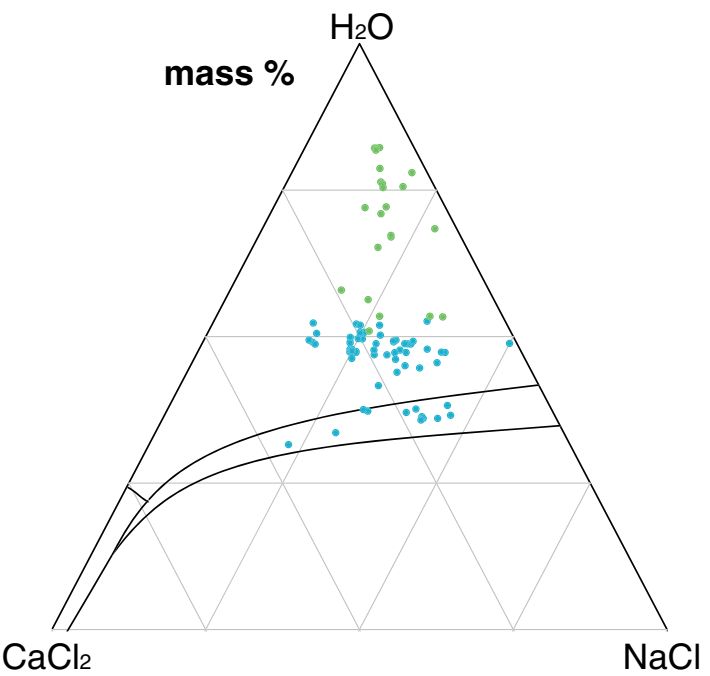

Primary fluid inclusions related to stage I are indicated in green. Primary fluid inclusions related to stage II are indicated in blue. c Fluid inclusions related to stage I and II fluorite in a ternary $\mathrm{H}_{2} \mathrm{O}-\mathrm{NaCl}-\mathrm{CaCl}_{2}$ plot (mass \%). d Close up view of the $\mathrm{H}_{2} \mathrm{O}$ apex of Fig. $6 \mathrm{c}$

caused by mixing of at least two chemically contrasting crustal fluids (Boiron et al. 2010; Walter et al. 2018a).

\section{Mechanisms of fluorite formation}

The solubility of fluorite in aqueous hydrothermal fluids is mainly dependent on $\mathrm{pH}$, temperature, and the chemical composition of the mineralizing fluid(s) (Barnes 2015; Richardson and Holland 1979). The latter authors have highlighted that the most efficient mechanisms for fluorite precipitation are fluid cooling, an increase of $\mathrm{pH}$, fluid-rock interaction, or mixing of two chemically contrasting fluids. Based on the fluid inclusion and REY evidence provided in this contribution, different processes of fluorite precipitation are invoked for the two stages observed at the Niederschlag deposit.

The range of homogenization temperatures documented by FIAs in fluorite I $\left(140\right.$ to $\left.180^{\circ} \mathrm{C}\right)$ does not appear large enough 
Table 2 REY-concentrations of fluorite stages I and II determined by Bulk solution ICP-MS

\begin{tabular}{|c|c|c|c|c|c|c|c|c|c|}
\hline $\mathrm{mg} / \mathrm{kg}$ & $\begin{array}{l}\text { SHFB-Nds- } \\
05 \\
\text { Stage II }\end{array}$ & $\begin{array}{l}\text { SHFB-Nds- } \\
03 \\
\text { Stage II }\end{array}$ & $\begin{array}{l}\text { SH-Nds- } \\
\text { PO8 } \\
\text { Stage II }\end{array}$ & $\begin{array}{l}\text { SH-Nds- } \\
\text { P14 } \\
\text { Stage I }\end{array}$ & $\begin{array}{l}\text { SH-Nds- } \\
\text { P7a } \\
\text { Stage II }\end{array}$ & $\begin{array}{l}\text { SH-Nds- } \\
\text { P7b } \\
\text { Stage II }\end{array}$ & $\begin{array}{l}\text { Mb-Ns- } \\
01 \\
\text { Stage I }\end{array}$ & $\begin{array}{l}\text { MbNs- } \\
02 \\
\text { Stage I }\end{array}$ & LOQ \\
\hline $\mathrm{Y}$ & 126.71 & 166.71 & 113.75 & 21.97 & 129.78 & 198.47 & 26.64 & 22.63 & 0.02 \\
\hline $\mathrm{La}$ & 2.00 & 3.66 & 2.00 & 17.30 & 4.77 & 4.40 & 10.16 & 23.08 & 0.02 \\
\hline $\mathrm{Ce}$ & 6.27 & 9.92 & 6.39 & 31.10 & 14.32 & 9.75 & 14.72 & 33.18 & 0.02 \\
\hline $\operatorname{Pr}$ & 1.21 & 1.69 & 1.28 & 5.39 & 2.33 & 1.45 & 3.33 & 6.98 & 0.01 \\
\hline $\mathrm{Nd}$ & 6.96 & 9.44 & 7.31 & 21.22 & 11.80 & 7.55 & 13.76 & 27.24 & 0.06 \\
\hline $\mathrm{Sm}$ & 4.35 & 6.79 & 4.23 & 2.93 & 5.32 & 4.44 & 2.98 & 3.54 & 0.08 \\
\hline $\mathrm{Eu}$ & 1.36 & 2.24 & 1.35 & 0.45 & 1.34 & 1.38 & 0.54 & 0.51 & 0.02 \\
\hline $\mathrm{Gd}$ & 10.06 & 15.97 & 8.66 & 2.25 & 9.78 & 12.42 & 2.86 & 2.39 & 0.04 \\
\hline $\mathrm{Tb}$ & 1.63 & 2.83 & 1.59 & 0.24 & 1.70 & 2.22 & 0.38 & 0.27 & 0.01 \\
\hline Dy & 10.02 & 16.66 & 10.75 & 1.49 & 11.17 & 14.87 & 2.47 & 1.49 & 0.04 \\
\hline Ho & 1.73 & 2.78 & 2.13 & 0.30 & 2.21 & 2.83 & 0.49 & 0.32 & 0.01 \\
\hline $\mathrm{Er}$ & 3.66 & 6.68 & 5.51 & 0.88 & 5.57 & 7.33 & 1.53 & 0.96 & 0.02 \\
\hline $\mathrm{Tm}$ & 0.35 & 0.79 & 0.71 & 0.13 & 0.68 & 0.81 & 0.24 & 0.15 & 0.01 \\
\hline $\mathrm{Yb}$ & 1.43 & 4.16 & 3.57 & 0.97 & 3.44 & 3.61 & 1.61 & 1.06 & 0.02 \\
\hline $\mathrm{Lu}$ & 0.17 & 0.56 & 0.50 & 0.16 & 0.47 & 0.47 & 0.25 & 0.16 & 0.01 \\
\hline
\end{tabular}

Abbreviations: $L O Q$ limit of quantification

to support cooling as a major precipitation mechanism. The high variablility of salinities (7-19\% eq. w) $\left(\mathrm{NaCl}-\mathrm{CaCl}_{2}\right)$ and the fairly constant $\mathrm{Na} / \mathrm{Ca}$ ratio indicate dilution of the ore-fluid with meteoric fluids, since admixing of a low salinity meteoric fluid would affect temperature and salinity, whereas the $\mathrm{Na} / \mathrm{Ca}$ would - considering the low absolute mass of dissolved solids in the meteoric fluid-remain constant. On the other hand, intense host rock alteration and the similarity of fluorite I and host rock $\mathrm{REY}_{\mathrm{SN}}$ patterns indicate that fluid-rock interaction may also have contributed to ore-formation. Stage I fluorite-quartz mineralization is intimately associated with intense host rock silicification and REY systematics of fluorite I suggest that the mineralizing system may have been rockbuffered. The reaction of an acidic hydrothermal fluid with host rock gneisses, schists, and marble releases, among others, $\mathrm{Ca}$ from plagioclase or carbonate minerals and concomitantly neutralizes the hydrothermal fluid. Increasing $\mathrm{Ca}$ activity and increasing $\mathrm{pH}$ are both favorable for fluorite precipitation.

Water-rock interaction with large volumina of granitoid rocks is widely regarded as possible source of fluorine to vein-hosted fluorite deposits similar to Stage II fluorite mineralization at Niederschlag (Burisch et al. 2016a; Seelig and Bucher 2010). However, recent studies have demonstrated that a sedimentary origin of fluorine in such systems is more likely (Burisch et al. 2016b; Burisch et al. 2018; Walter et al. 2018a). Mixing of a Ca-rich deep-seated basement brine with a shallower fluorine-bearing sedimentary fluid is thus considered the most important process of mineral formation for the Stage II fluorite-barite-sulfide assemblage at the Niederschlag deposit.

\section{Mineralizing systems}

To our knowledge, there are no analogues to the Stage I fluorite-quartz mineralization documented here for the Niederschlag deposit anywhere else in Central Europe. This, combined with the current lack of geochronological data, renders the identification of a regional geotectonic context difficult for this mineralization stage. However, massive fluorite veins in Central Chinese Orogenic Belt (CCOB, (Pei et al. 2017; Pei et al. 2019; Xiang et al. 2010)) have many characteristics (mineralogy, texture, and geochemistry) similar to

Table 3 Overview of genetic characteristics of stage I and II mineralization

\begin{tabular}{lll}
\hline & Stage I mineralization & Stage II mineralization \\
\hline Analogues & Vein-type fluorite deposits in the Central Chinese Orogenic Belt & Fluorite-barite Pb-Zn-Cu deposits across Europe \\
Precipitation mechanism & Mixing with meteoric fluids and host rock interaction & Fluid mixing of basement and sedimentary fluids \\
Source of fluorine & Possibly Li-F-granites & Likely sedimentary derived F \\
Geotectonic setting & Lower Permian post-orogenic rifting & Mesozoic rifting \\
\hline
\end{tabular}




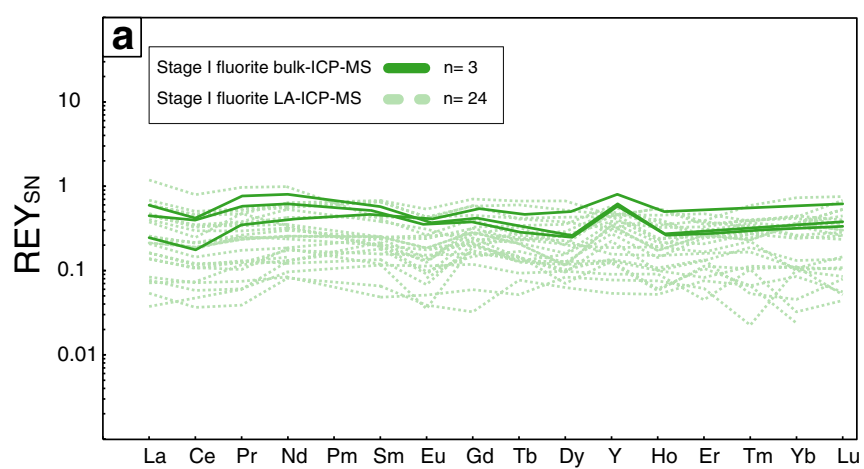

Fig. 7 LA-ICP-MS (dotted lines) and bulk ICP-MS (straight lines) analyses of stage I and II fluorites normalized to European shale (Bau et al. 2018). a In situ (dotted lines) and bulk (straight lines) fluorite analyses of stage I have flat patterns. They invariably exhibit minor negative $\mathrm{Ce}$ and positive $\mathrm{Y}$ anomalies. b In-situ (dotted lines) and bulk (straight lines)

fluorite I mineralization. The formation of such massive fluorite veins in the $\mathrm{CCOB}$ coincides with intense post-orogenic magmatic activity. This is similar to the geotectonic evolution in the Erzgebirge in the immediate aftermath of the Variscan Orogeny in the Permian. Assuming that the formation of fluorite is related to post-orogenic rifting, formation temperatures of FIs between 140 and $180{ }^{\circ} \mathrm{C}$ suggest a significantly enhanced geothermal gradient of $70-80^{\circ} \mathrm{C} / \mathrm{km}$, taking into account that not more than $2 \mathrm{~km}$ of Variscan basement have been eroded since Permian times (Bauer et al. 2019; Wolff et al. 2015a). Such an elevated geothermal gradient at shallow crustal levels would, in turn, be indicative of a distal/shallow magmatic-hydrothermal environment (Browne and Ellis 1970; Simmons et al. 2005; Simmons and Browne 2000). This is in good agreement with fluid composition marked by low $\mathrm{pH}$ and devoid of sulfur and base metals (Table 3). Such a fluid may well have been associated with Late Variscan high$F$ granitoids that abound in the area around the Niederschlag deposit (e.g., Eibenstock granite). Such granites may well have served directly (fractional crystallization) or indirectly (sub-solidus leaching) as the source of fluorine.

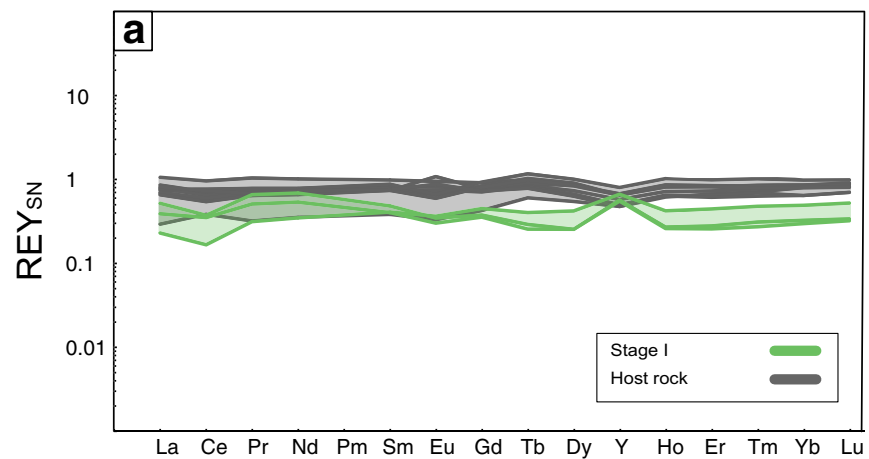

Fig. 8 Shale-normalized REY diagrams of Niederschlag fluorites in comparison to literature data. a Range of fluorite I analyses (this study) are indicated in green, REY pattern of the gneisses, and micaschists that are hosted by lithologies of the Niederschlag deposit are indicated as gray lines (Mingram et al. 2004). b The dark blue area indicates the range of

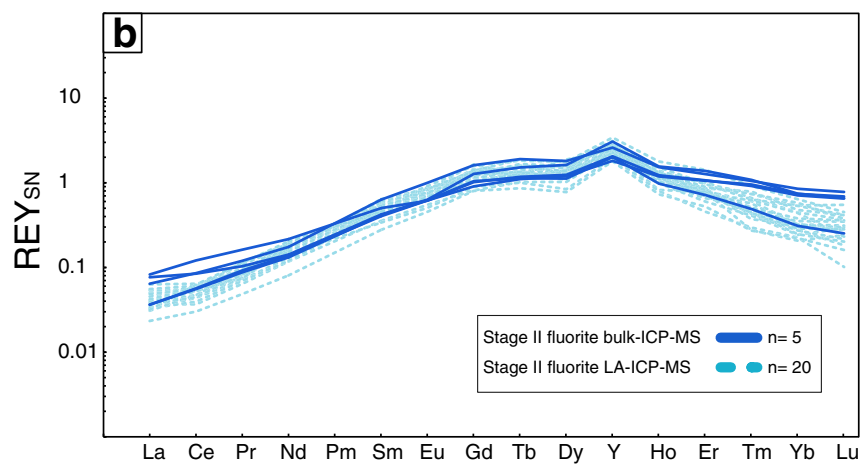

fluorite analyses of stage II fluorite. Compared to fluorite I these are depleted in LREE, substantially enriched in MREE, and slightly enriched in HREE. Compared to fluorite I, fluorite II shows a distinct positive Yanomaly

In contrast, stage II fluorite-barite-sulfide mineralization of the Niederschlag deposit shares close similarities to other vein-hosted fluorite deposits in the Erzgebirge (Bauer et al. 2019; Ostendorf et al. 2019) and elsewhere across Central Europe. Therefore, it is most likely that the formation of Stage II fluorite at the Niederschlag deposit is related to the far-field effects of the opening of the northern Atlantic during the Mesozoic (Table 3). In this extensional system, fluid mixing occurs across fluid unconformities (i.e., interface between two chemically contrasting fluids; Bons et al. 2014; Burisch et al. 2016b; Burisch et al. 2018) near the base of sedimentary basins (Boiron et al. 2010; Richard et al. 2013). The nature of the sedimentary basin present at that time is not well constrained for the Erzgebirge. However, Jurassic marine sediments are recorded in the nearby Elbe zone, and apatite UHe ages suggest that a $3-5 \mathrm{~km}$ thick cover was present during the Jurassic (Wolff et al. 2015a). The thickness of this sedimentary cover constrains the minimum depth of formation of Stage II fluorite. Homogenization temperatures are consistent with this consideration, if a normal to the slightly elevated geothermal gradient $\left(25-35^{\circ} \mathrm{C}\right)$ is assumed.

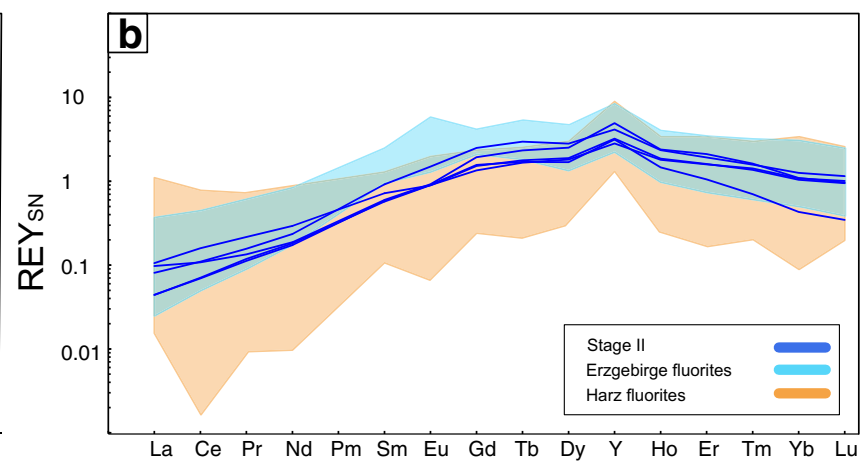

fluorite II analyses of this study, the light blue area refers to analyses of fluorite from Freiberg (Trinkler et al. 2005), Erzgebirge, and the yellow area indicates analyses of fluorites from various deposits in the Harz Mountains (Alles et al. 2018) 


\section{Conclusions}

Two very distinct stages of fluorite mineralization can be recognized at the Niederschlag deposit. These two stages are not only different by mineral assemblage and textural appearance but also by fluid inclusion systematics and REY trace element distribution. These differences document profound disparities in the nature of the two mineralizing systems that both explored the same structural conduit at different times. The Stage I fluorite-quartz assemblage has attributes akin to a shallow (magmatic-) hydrothermal environment that can be related to Permian orogenic collapse and subsequent rifting in the Erzgebirge. This is the first time that (circumstantial) evidence links the formation of a large fluorite deposit with this otherwise prolific metallogenetic period. In contrast, Stage II fluorite - closely associated with barite and base metal sulfides - has striking similarities to other fluorite-barite deposits in Central Europe. It can therefore be safely associated with the opening of the Atlantic during the Mesozoic.

Supplementary Information The online version contains supplementary material available at https://doi.org/10.1007/s00126-020-01035-y .

Acknowledgments We would like to thank Bernd Lehmann and Hartwig Frimmel for the editorial handling as well as Sophie Decrée and an anonymous reviewer for their constructive comments that significantly helped to improve an earlier version of this manuscript. Moreover, we would like to thank R. Würkert, M. Stoll, and A. Bartzsch (Helmholtz-Institute Freiberg for Resource Technology) for sample preparation. S. Gilbricht is thanked for support at the electron microscope and Jens Götze for help with the CL imaging. Furthermore, we would like to thank H. Ehle and M. Zimmermann (both EFS) for giving us access to the underground mine and supporting us during sampling. Staff of the Sächsisches Landesamt für Umwelt und Geologie supported this study: M. Lapp is thanked for providing access to drill cores and historic mine plans and Uwe Lehmann for providing photographs of the underground exposure of fluorite I. Furthermore, we would like to thank G. Markl and M. Frenzel as well as M. Guilcher, L. Swinkels, and N. Reinhardt for insightful discussions.

Funding Open Access funding enabled and organized by Projekt DEAL. This study is funded by the European Social Fund (ESF) and the Federal State of Saxony (Grant number 10033945 awarded to M. Burisch).

Supplementary Information The online version contains supplementary material available at https://doi.org/10.1007/s00126-020-01035-y .

Open Access This article is licensed under a Creative Commons Attribution 4.0 International License, which permits use, sharing, adaptation, distribution and reproduction in any medium or format, as long as you give appropriate credit to the original author(s) and the source, provide a link to the Creative Commons licence, and indicate if changes were made. The images or other third party material in this article are included in the article's Creative Commons licence, unless indicated otherwise in a credit line to the material. If material is not included in the article's Creative Commons licence and your intended use is not permitted by statutory regulation or exceeds the permitted use, you will need to obtain permission directly from the copyright holder. To view a copy of this licence, visit http://creativecommons.org/licenses/by/4.0/.

\section{References}

Alles J, Ploch A-M, Schirmer T, Nolte N, Liessmann W, Lehmann B (2018) Rare-earth-element enrichment in post-Variscan polymetallic vein systems of the Harz Mountains, Germany. Mineral Deposita 119:213-328. https://doi.org/10.1007/s00126018-0847-8

Baatartsogt B, Schwinn G, Wagner T, Taubald H, Beitter T, Markl G (2007) Contrasting paleofluid systems in the continental basement: a fluid inclusion and stable isotope study of hydrothermal vein mineralization, Schwarzwald district, Germany. Geofluids 7:123-147. https://doi.org/10.1111/j.1468-8123.2007.00169.x

Barnes H (2015) Hydrothermal processes: the development of geochemical concepts in the latter half of the twentieth century. Geochem Persp 4:1-93. https://doi.org/10.7185/geochempersp.4.1

Bau M, Dulski P (1995) Comparative study of yttrium and rare-earth element behaviours in fluorine-rich hydrothermal fluids. Contrib Mineral Petrol 119:213-223. https://doi.org/10.1007/BF00307282

Bau M, Schmidt K, Pack A, Bendel V, Kraemer D (2018) The European shale: an improved data set for normalisation of rare earth element and yttrium concentrations in environmental and biological samples from Europe. Appl Geochem 90:142-149. https://doi.org/10.1016/j. apgeochem.2018.01.008

Bauer ME, Burisch M, Ostendorf J, Krause J, Frenzel M, Seifert T, Gutzmer J (2019) Trace element geochemistry of sphalerite in contrasting hydrothermal fluid systems of the Freiberg district, Germany: insights from LA-ICP-MS analysis, near-infrared light microthermometry of sphalerite-hosted fluid inclusions, and sulfur isotope geochemistry. Mineral Deposita 52:651-262. https://doi. org/10.1007/s00126-018-0850-0

Baumann L, Kuschka E, Seifert T (2000) Lagerstätten des Erzgebirges: 13 Tabellen. Enke im Thieme-Verl., Stuttgart

Boiron M-C, Cathelineau M, Richard A (2010) Fluid flows and metal deposition near basement /cover unconformity: lessons and analogies from $\mathrm{Pb}-\mathrm{Zn}$-F-Ba systems for the understanding of Proterozoic U deposits. Geofluids 44:41. https://doi.org/10.1111/j.1468-8123. 2010.00289.x

Bons PD, Fusswinkel T, Gomez-Rivas E, Markl G, Wagner T, Walter B (2014) Fluid mixing from below in unconformity-related hydrothermal ore deposits. Geology 42:1035-1038. https://doi.org/10.1130/ G35708.1

Browne PRL, Ellis AJ (1970) The Ohaki-Broadlands hydrothermal area, New Zealand; mineralogy and related geochemistry. Am J Sci 269: 97-131. https://doi.org/10.2475/ajs.269.2.97

Burisch M, Marks MAW, Nowak M, Markl G (2016a) The effect of temperature and cataclastic deformation on the composition of upper crustal fluids - an experimental approach. Chem Geol 433:24-35. https://doi.org/10.1016/j.chemgeo.2016.03.031

Burisch M, Walter BF, Wälle M, Markl G (2016b) Tracing fluid migration pathways in the root zone below unconformity-related hydrothermal veins: insights from trace element systematics of individual fluid inclusions. Chem Geol 429:44-50. https://doi.org/10.1016/j. chemgeo.2016.03.004

Burisch M, Walter BF, Markl G (2017) Silicification of hydrothermal gangue minerals in $\mathrm{Pb}-\mathrm{Zn}$-cu-fluorite-quartz-Baryte veins. Can Mineral 55:501-514. https://doi.org/10.3749/canmin.1700005

Burisch M, Walter BF, Gerdes A, Lanz M, Markl G (2018) Late-stage anhydrite-gypsum-siderite-dolomite-calcite assemblages record the transition from a deep to a shallow hydrothermal system in the Schwarzwald mining district, SW Germany. Geochim Cosmochim Acta 223:259-278. https://doi.org/10.1016/j.gca.2017.12.002

Burisch M, Gerdes A, Meinert LD, Albert R, Seifert T, Gutzmer J (2019) The essence of time - fertile skarn formation in the Variscan Orogenic Belt. Earth Planet Sci Lett 519:165-170. https://doi.org/ 10.1016/j.epsl.2019.05.015 
EU Commission (2017) Study on the review of the list of critical raw materials: Final report

Förster H-J, Tischendorf G, Trumbull RB, Gottesmann B (1999) Latecollisional granites in the Variscan Erzgebirge, Germany. J Petrol 40:1613-1645. https://doi.org/10.1093/petrology/40.11.1613

Förster H-J, Gottesmann B, Tischendorf G, Siebel W, Rhede D, Seltmann R, Wasternack J (2007) Permo-carboniferous subvolcanic rhyolitic dikes in the western Erzgebirge/Vogtland, Germany: a record of source heterogeneity of post-collisional felsic magmatism. $\mathrm{N} \mathrm{Jb}$ Mineral (Abh) 183:123-147. https://doi.org/10.1127/0077-7757/ 2007/0064

Friedländer M (2019) Kontaktmetamorphe Überprägung eines Fluoritganges durch einen phonolithischen Dyke, Niederschlag. Bachelor thesis, TU-Bergakedemie Freiberg

Fusswinkel T, Wagner T, Wälle M, Wenzel T, Heinrich CA, Markl G (2013) Fluid mixing forms basement-hosted $\mathrm{Pb}-\mathrm{Zn}$ deposits: insight from metal and halogen geochemistry of individual fluid inclusions. Geol 41:679-682. https://doi.org/10.1130/G34092.1

Gagnon JE, Samson IM, Fryer BJ, Williams-Jones AE (2003) Compositional heterogeneity in fluorite and the genesis offluorite deposits: insights from la icp ms analysis. The Canadian Mineralogist 41:365-382

Gleeson SA, Wilkinson JJ, Stuart FM, Banks DA (2001) The origin and evolution of base metal mineralising brines and hydrothermal fluids, South Cornwall, UK. Geochim Cosmochim Acta 65:2067-2079. https://doi.org/10.1016/S0016-7037(01)00579-8

Hoffmann U, Breitkreuz C, Breiter K, Sergeev S, Stanek K, Tichomirowa M (2013) Carboniferous-Permian volcanic evolution in Central Europe - $\mathrm{U} / \mathrm{Pb}$ ages of volcanic rocks in Saxony (Germany) and northern Bohemia (Czech Republic). Int J Earth Sci (Geol Rundsch) 102:73-99. https://doi.org/10.1007/s00531-012-0791-2

Keim MF, Walter BF, Neumann U, Kreissl S, Bayerl R, Markl G (2018) Polyphase enrichment and redistribution processes in silver-rich mineral associations of the hydrothermal fluorite-barite- $(\mathrm{Ag}-\mathrm{Cu})$ Clara deposit, SW Germany. Mineral Deposita 50:51-174. https:// doi.org/10.1007/s00126-018-0799-z

Korges M, Weis P, Lüders V, Laurent O (2019) Sequential evolution of Sn-Zn-In mineralization at the skarn-hosted Hämmerlein deposit, Erzgebirge, Germany, from fluid inclusions in ore and gangue minerals. Mineral Deposita 95:1563-1952. https://doi.org/10.1007/ s00126-019-00905-4

Kraemer D, Viehmann S, Banks D, Sumoondur AD, Koeberl C, Bau M (2019) Regional variations in fluid formation and metal sources in MVT mineralization in the Pennine Orefield, UK: implications from rare earth element and yttrium distribution, $\mathrm{Sr}-\mathrm{Nd}$ isotopes and fluid inclusion compositions of hydrothermal vein fluorites. Ore Geol Rev 107:960-972. https://doi.org/10.1016/j.oregeorev.2019.03.014

Kroner U, Romer RL (2013) Two plates - many subduction zones: the Variscan orogeny reconsidered. Gondwana Res 24:298-329. https:// doi.org/10.1016/j.gr.2013.03.001

Kröner A, Willner AP (1998) Time of formation and peak of Variscan HP-HT metamorphism of quartz-feldspar rocks in the central Erzgebirge, Saxony, Germany. Contrib Mineral Petrol 132:1-20. https://doi.org/10.1007/s004100050401

Kuhn K, Duba J (eds) (2017) Fluss- und Schwerspat in Deutschland, Stand: November 2017. Bundesanstalt für Geowissenschaften und Rohstoffe (BGR), Hannover

Kuschka E. (2002) Die Uranerz-Baryt-Fluorit-Lagerstätte Niederschlag bei Bärenstein und benachbarte Erzvorkommen. Geoprofil, vol 6 . Sächsisches Landesamt für Umwelt und Geologie, Freiberg

Kuschka E, Hahn W (1996) Flußspatlagerstättendes Südwestvogtlandes Schönbrunn, Bösenbrunn, Wiedersberg. Geoprofil 1996

Lefebvre MG, Romer RL, Glodny J, Roscher M (2019) Skarn formation and tin enrichment during regional metamorphism: the Hämmerlein polymetallic skarn deposit. Lithos 348-349:105171. https://doi.org/ 10.1016/j.lithos.2019.105171
Leonhardt, D (1999) Geologische Karte des Freistaates Sachsen im Maßstab 1 : 25.000; Blatt-Nr. 5543 Kurort Oberwiesenthal Sächs. Landesamt für Umwelt und Geologie, Bereich Boden und Geologie, 3. Aufl.: 111 S., 1 Anl., Freiberg, 1999.

Lipp and Flach (2003) Wismut-, Kobalt-, Nickel- und Silbererze im Nordteil des Schneeberger Lagerstättenbezirkes. Bergbau in Sachsen Bergbaumonographie, vol 10. Sächsisches Landesamt für Umwelt und Geologie (LfUG)

Loges A, Migdisov AA, Wagner T, Williams-Jones AE, Markl G (2013) An experimental study of the aqueous solubility and speciation of $Y$ (III) fluoride at temperatures up to $250^{\circ} \mathrm{C}$. Geochim Cosmochim Acta 123:403-415. https://doi.org/10.1016/j.gca.2013.07.031

Mingram B (1998) The Erzgebirge, Germany, a subducted part of northern Gondwana: geochemical evidence for repetition of early Palaeozoic metasedimentary sequences in metamorphic thrust units. Geol Mag 135:785-801. https://doi.org/10.1017/ S0016756898001769

Mingram B, Kroener A, Hegner E, Krentz O (2004) Zircon ages, geochemistry, and $\mathrm{Nd}$ isotopic systematics of pre-Variscan orthogneisses from the Erzgebirge, Saxony (Germany), and geodynamic interpretation. Int J Earth Sci (Geol Rundsch) 93: 706-727. https://doi.org/10.1007/s00531-004-0414-7

Moeller P, Bau M (1993) Rare-earth patterns with positive cerium anomaly in alkaline waters from Lake Van, Turkey. Earth Planet Sci Lett 1993:671-676

Muchez P, Heijlen W, Banks D, Blundell D, Boni M, Grandia F (2005) 7: extensional tectonics and the timing and formation of basin-hosted deposits in Europe. Ore Geol Rev 27:241-267. https://doi.org/10. 1016/j.oregeorev.2005.07.013

Nadoll P, Sośnicka M, Kraemer D, Duschl F (2019) Post-Variscan structurally-controlled hydrothermal $\mathrm{Zn}-\mathrm{Fe}$ - $\mathrm{Pb}$ sulfide and $\mathrm{F}-\mathrm{Ba}$ mineralization in deep-seated Paleozoic units of the North German Basin: a review. Ore Geol Rev 106:273-299. https://doi.org/10.1016/j. oregeorev.2019.01.022

Neuser RD, Bruhn F, Götze J, Habermann D, Richter DK (1995) Kathodolumineszenz: Methodik und Anwendung.: Cathodoluminescence: method and application. Zentralblatt für Geologie und Paläontologie, Teil I 1:287-306

Ostendorf J, Henjes-Kunst F, Seifert T, Gutzmer J (2019) Age and genesis of polymetallic veins in the Freiberg district, Erzgebirge, Germany: constraints from radiogenic isotopes. Mineral Deposita 38:992-236. https://doi.org/10.1007/s00126-018-0841-1

Pälchen W, Walter H (2008) Geologie von Sachsen I. Schweizerbart'sche Verlagsbuchhandlung, Stuttgart

Paton C, Hellstrom J, Paul B, Woodhead J, Hergt J (2011) Iolite: freeware for the visualisation and processing of mass spectrometric data. $\mathrm{J}$ Anal At Spectrom 26:2508. https://doi.org/10.1039/c1ja10172b

Pei Q, Zhang S, Santosh M, Cao H, Zhang W, Hu X, Wang L (2017) Geochronology, geochemistry, fluid inclusion and $\mathrm{C}, \mathrm{O}$ and $\mathrm{Hf}$ isotope compositions of the Shuitou fluorite deposit, Inner Mongolia, China. Ore Geol Rev 83:174-190. https://doi.org/10.1016/j. oregeorev.2016.12.022

Pei Q, Zhang S, Hayashi K-i, Wang L, Cao H, Zhao Y, Hu X, Song K, Chao W (2019) Nature and genesis of the Xiaobeigou fluorite deposit, Inner Mongolia, northeast China: evidence from fluid inclusions and stable isotopes. Resour Geol 69:148-166. https://doi.org/ $10.1111 /$ rge. 12191

Richard A, Boulvais P, Mercadier J, Boiron M-C, Cathelineau M, Cuney M, France-Lanord C (2013) From evaporated seawater to uraniummineralizing brines: isotopic and trace element study of quartzdolomite veins in the Athabasca system. Geochim Cosmochim Acta 113:38-59. https://doi.org/10.1016/j.gca.2013.03.009

Richardson CK, Holland HD (1979) Fluorite deposition in hydrothermal systems. Geochim Cosmochim Acta 43:1327-1335. https://doi.org/ 10.1016/0016-7037(79)90122-4 
Romer RL, Förster H-J, Štemprok M (2010) Age constraints for the lateVariscan magmatism in the Altenberg-Teplice Caldera (Eastern Erzgebirge/Krušné hory). N Jb Mineral (Abh) 187:289-305. https://doi.org/10.1127/0077-7757/2010/0179

Rötzler K, Plessen B (2010) The Erzgebirge: a pile of ultrhigh- to lowpressure nappes of Early Paleazoic rocks and their Cadomian basement. In: Linnemann U (ed) Pre-Mesozoic geology of SaxoThuringia: From the Cadomian active margin to the Variscan orogen ; with 6 tables, 1 fold-out and 1 sheet map, supplementary data on DVD. Schweizerbart, Stuttgart, pp. 253-270

Sánchez V, Cardellach E, Corbella M, Vindel E, Martín-Crespo T, Boyce AJ (2010) Variability in fluid sources in the fluorite deposits from Asturias (N Spain): further evidences from REE, radiogenic (Sr, Sm, $\mathrm{Nd})$ and stable $(\mathrm{S}, \mathrm{C}, \mathrm{O})$ isotope data. Ore Geol Rev 37:87-100. https://doi.org/10.1016/j.oregeorev.2009.12.001

Sander MV, Black JE (1988) Crystallization and recrystallization of growth-zoned vein quartz crystals from epithermal systemsimplications for fluid inclusion studies. Econ Geol 83:1052-1060

Schwinn G, Markl G (2005) REE systematics in hydrothermal fluorite. Chem Geol 216:225-248. https://doi.org/10.1016/j.chemgeo.2004. 11.012

Seelig U, Bucher K (2010) Halogens in water from the crystalline basement of the Gotthard rail base tunnel (Central Alps). Geochim Cosmochim Acta 74:2581-2595. https://doi.org/10.1016/j.gca. 2010.01 .030

Seifert T (2008) Metallogeny and petrogenesis of lamprophyres in the Mid-European variscides: Post-collosional magmatism and its relationship to late-variscan ore forming processes in the Erzgebirge (Bohemian Massif). IOS Press Millpress; Gazelle Books Distr, Amsterdam, Hightown

Simmons SF, Browne PRL (2000) Hydrothermal minerals and precious metals in the Broadlands-Ohaaki geothermal system: implications for understanding low-Sulfidation epithermal environments. Econ Geol 95:971-999. https://doi.org/10.2113/gsecongeo.95.5.971

Simmons SF, White NC, John DA (2005) Geological characteristics of epithermal precious and base metal deposits. In: Hedenquist JW (ed) Economic geology: one hundredth anniversary volume : 19052005. Society of Economic Geologists, Inc, Littleton, pp 455-522

Steele-MacInnis M, Bodnar RJ, Naden J (2011) Numerical model to determine the composition of $\mathrm{H} 2 \mathrm{O}-\mathrm{NaCl}-\mathrm{CaCl} 2$ fluid inclusions based on microthermometric and microanalytical data. Geochim Cosmochim Acta 75:21-40. https://doi.org/10.1016/j.gca.2010.10. 002

Tichomirowa M, Leonhardt D (2010) New age determinations $(\mathrm{Pb} / \mathrm{Pb}$ zircon evaporation, $\mathrm{Rb} / \mathrm{Sr}$ ) on the granites from AueSchwarzenberg and Eibenstock, Western Erzgebirge, Germany. Zeitung für geologische Wissenschaft:99-123

Tichomirowa M, Sergeev S, Berger H-J, Leonhardt D (2012) Inferring protoliths of high-grade metamorphic gneisses of the Erzgebirge using zirconology, geochemistry and comparison with lower-grade rocks from Lusatia (Saxothuringia, Germany). Contrib Mineral Petrol 164:375-396. https://doi.org/10.1007/s00410-012-0742-8

Trinkler M, Monecke T, Thomas R (2005) Constraints on the genesis of yellow fluorite in hydrothermal barite-fluorite veins of the Erzgebirge, EASTERN Germany: evidence from optical absorption spectroscopy, rare-earth-element data, and fluid-inclusion investigations. Can Mineral 2005:883-898

Ulrych J, Dostal J, Adamovič J, Jelínek E, Špaček P, Hegner E, Balogh K (2011) Recurrent Cenozoic volcanic activity in the Bohemian Massif (Czech Republic). Lithos 123:133-144. https://doi.org/10. 1016/j.lithos.2010.12.008 van den Kerkhof AM, Hein UF (2001) Fluid inclusion petrography. Lithos 55:27-47. https://doi.org/10.1016/S0024-4937(00)00037-2

von Seckendorff V, Timmerman MJ, Kramer W, Wrobel P (2004) New $40 \mathrm{Ar} / 39 \mathrm{Ar}$ ages and geochemistry of late Carboniferous-early Permian lamprophyres and related volcanic rocks in the Saxothuringian Zone of the Variscan Orogen (Germany). Geol Soc Lond, Spec Publ 223:335-359. https://doi.org/10.1144/GSL. SP.2004.223.01.15

Wagenbreth O (ed) (1988) Der Freiberger Bergbau: Technische Denkmale und Geschichte, 2. Auflage 1988. Nachdruck 2015. Springer Berlin Heidelberg, Berlin, Heidelberg, s.l

Walter BF, Burisch M, MARKL G (2016) Long-term chemical evolution and modification of continental basement brines - a field study from the Schwarzwald, SW Germany. Geofluids 16:604-623. https://doi. org/10.1111/gfl.12167

Walter BF, Burisch M, Marks MAW, MARKL G (2017) Major element compositions of fluid inclusions from hydrothermal vein-type deposits record eroded sedimentary units in the Schwarzwald district, SW Germany. Mineral Deposita 2017:1191-1204

Walter BF, Burisch M, Fusswinkel T, Marks MAW, Steele-MacInnis M, Wälle M, Apukhtina OB, Markl G (2018a) Multi-reservoir fluid mixing processes in rift-related hydrothermal veins, Schwarzwald, SW-Germany. J Geochem Explor 186:158-186. https://doi.org/10. 1016/j.gexplo.2017.12.004

Walter BF, Gerdes A, Kleinhanns IC, Dunkl I, von Eynatten H, Kreissl S, Markl G (2018b) The connection between hydrothermal fluids, mineralization, tectonics and magmatism in a continental rift setting: fluorite $\mathrm{Sm}-\mathrm{Nd}$ and hematite and carbonates $\mathrm{U}-\mathrm{Pb}$ geochronology from the Rhinegraben in SW Germany. Geochim Cosmochim Acta 240:11-42. https://doi.org/10.1016/j.gca.2018.08.012

Walther H (2005) Vulkanische Floren der südöstlichen Oberlausitz und des böhmischen Mittelgebirges - Zeugen der tertiären Waldentwicklung in Mitteleuropa. Berichte der Naturforschenden Gesellschaft der Oberlausitz

Wismut GmbH (1999): Chronik der Wismut. Chemnitz: Wismut GmbH. CD-ROM

Wolff R, Dunkl I, Lange J-M, Tonk C, Voigt T, von Eynatten H (2015a) Superposition of burial and hydrothermal events: post-Variscan thermal evolution of the Erzgebirge, Germany. Terra Nova 27: 292-299. https://doi.org/10.1111/ter.12159

Wolff R, Dunkl I, Kempe U, Eynatte H v (2015b) The age of the latest thermal overprint of tin and polymetallic deposits in the Erzgebirge, Germany: constraints from fluorite (U-Th-Sm)/He thermochronology*. Econ Geol:2025-2040

Woodhead J, Hellstrom J, Hergt J, Greig A, Maas R (2007) Isotopic and elemental imaging of geological materials by laser ablation inductively coupled plasma-mass spectrometry. Geostand Geoanalytical Res 31:331-343

Xiang S, Jun D, Liqiang Y, Qingfei W, Zirong Y, Qingjie G, Changming W (2010) REE and Sr-Nd isotope geochemistry for Yixian fluorite deposit, western Liaoning Province, China, and its geological implications. J Earth Sci 21:227-235. https://doi.org/10.1007/s12583010-0020-5

Zhang R, Lehmann B, Seltmann R, Sun W, Li C (2017) Cassiterite U-Pb geochronology constrains magmatic-hydrothermal evolution in complex evolved granite systems: the classic Erzgebirge tin province (Saxony and Bohemia). Geology 45:1095-1098. https://doi. org/10.1130/G39634.1

Publisher's note Springer Nature remains neutral with regard to jurisdictional claims in published maps and institutional affiliations. 